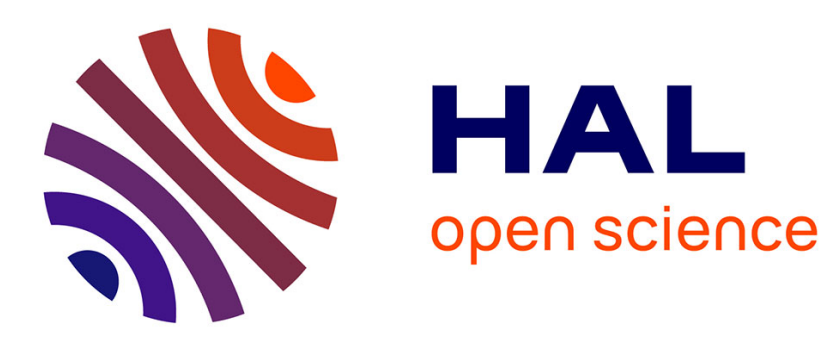

\title{
Hydroxyapatite-TiO2-SiO2-Coated 316L Stainless Steel for Biomedical Application
}

Djahida Sidane, Hafit Khireddine, Fatima Bir, Sabeha Yala, Alex Montagne, Didier Chicot

\section{- To cite this version:}

Djahida Sidane, Hafit Khireddine, Fatima Bir, Sabeha Yala, Alex Montagne, et al.. HydroxyapatiteTiO2-SiO2-Coated 316L Stainless Steel for Biomedical Application. Metallurgical and Materials Transactions A, 2017, 48 (7), pp.3570-3582. 10.1007/s11661-017-4108-8 . hal-01565674

\section{HAL Id: hal-01565674 \\ https://hal.science/hal-01565674}

Submitted on 22 Aug 2017

HAL is a multi-disciplinary open access archive for the deposit and dissemination of scientific research documents, whether they are published or not. The documents may come from teaching and research institutions in France or abroad, or from public or private research centers.
L'archive ouverte pluridisciplinaire HAL, est destinée au dépôt et à la diffusion de documents scientifiques de niveau recherche, publiés ou non, émanant des établissements d'enseignement et de recherche français ou étrangers, des laboratoires publics ou privés. 


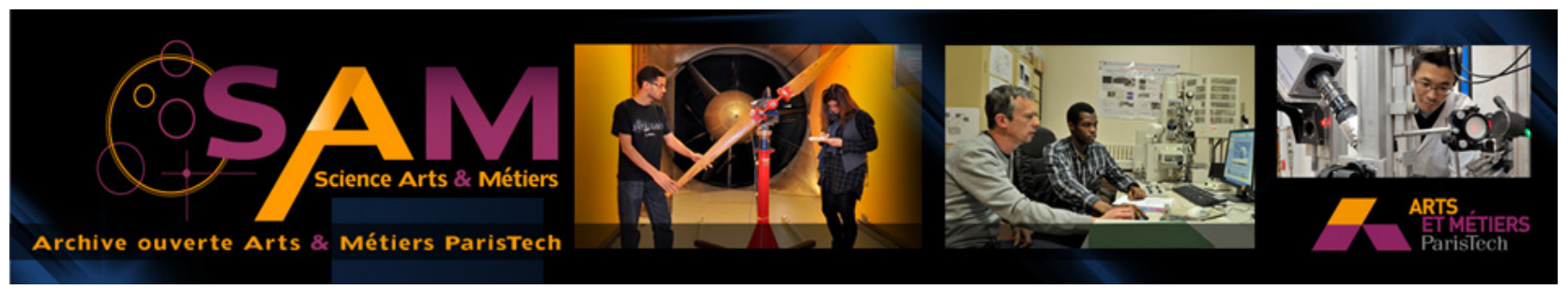

\section{Science Arts \& Métiers (SAM)}

is an open access repository that collects the work of Arts et Métiers ParisTech researchers and makes it freely available over the web where possible.

This is an author-deposited version published in: http://sam.ensam.eu

Handle ID: .http://hdl.handle.net/null

\section{To cite this version :}

DJAHIDA SIDANE, HAFIT KHIREDDINE, FATIMA BIR, SABEHA YALA, Alex MONTAGNE, Didier CHICOT - Hydroxyapatite-TiO2-SiO2-Coated 316L Stainless Steel for Biomedical Application - Metallurgical and Materials Transactions A - Vol. 48, nº7, p.3570-3582 - 2017 


\title{
Hydroxyapatite- $\mathrm{TiO}_{2}-\mathrm{SiO}_{2}$-Coated 316L Stainless Steel for Biomedical Application
}

\author{
DJAHIDA SIDANE, HAFIT KHIREDDINE, FATIMA BIR, SABEHA YALA, \\ ALEX MONTAGNE, and DIDIER CHICOT
}

This study investigated the effectiveness of titania $\left(\mathrm{TiO}_{2}\right)$ as a reinforcing phase in the hydroxyapatite (HAP) coating and silica $\left(\mathrm{SiO}_{2}\right)$ single layer as a bond coat between the $\mathrm{TiO}_{2}$-reinforced hydroxyapatite $\left(\mathrm{TiO}_{2} / \mathrm{HAP}\right)$ top layer and $316 \mathrm{~L}$ stainless steel (316L SS) substrate on the corrosion resistance and mechanical properties of the underlying $316 \mathrm{~L} \mathrm{SS}$ metallic implant. Single layer of $\mathrm{SiO}_{2}$ film was first deposited on 316L SS substrate and studied separately. Water contact angle measurements, X-ray photoelectron spectroscopy, and Fourier transform infrared spectrophotometer analysis were used to evaluate the hydroxyl group reactivity at the $\mathrm{SiO}_{2}$ outer surface. The microstructural and morphological results showed that the reinforcement of HAP coating with $\mathrm{TiO}_{2}$ and $\mathrm{SiO}_{2}$ reduced the crystallite size and the roughness surface. Indeed, the deposition of $50 \mathrm{vol}$ pet $\mathrm{TiO}_{2}$-reinforced hydroxyapatite layer enhanced the hardness and the elastic modulus of the HAP coating, and the introduction of $\mathrm{SiO}_{2}$ inner layer on the surface of the 316L SS allowed the improvement of the bonding strength and the corrosion resistance as confirmed by scratch studies, nanoindentation, and cyclic voltammetry tests.

\section{INTRODUCTION}

HydroXYAPATITE $\left(\mathrm{Ca}_{10}\left(\mathrm{PO}_{4}\right)_{6}(\mathrm{OH})_{2}, \mathrm{HAP}\right)$ is found to be the preferred bioactive ceramic due to its chemical, structural, and biological similarity to the inorganic component of human bones and to its direct bonding capability to surrounding tissues. ${ }^{[1]}$ However, the mechanical weakness of the HAP limits its practical applications to those requiring little or no load-bearing locations. Therefore, to widen the applicability of the HAP to the sites bearing substantial load, such as dental or hip implant, a coating system including HAP on the metallic implant is being used. Metallic materials such as 316L stainless steel (316L SS), Co-Cr alloy, Ti, and Ti-6Al-4V alloy are widely used biomaterials for hard tissue replacement due to their superior tensile strength, fracture toughness, corrosion resistance, and biocompatibility with the internal human environment. ${ }^{[2-5]}$ 316L SS is used in orthopaedic medical fields due to its unique property of biocompatibility, cost effectiveness, and corrosion resistance. ${ }^{[6,7]}$ It is shown that the introduction of an intermediate thin layer of titania $\left(\mathrm{TiO}_{2}\right)$, which possesses combined advantages of biocompatibility and corrosion resistance properties, ${ }^{[8,9]}$ between the metal substrate and the HAP layer significantly improves the mechanical properties and corrosion resistance of the HAP coatings. ${ }^{[10-14]}$ On the other side, a large number of articles have reported that the addition of $\mathrm{TiO}_{2}$ as secondary phase into HAP coatings improved the mechanical and bonding strength of the HAP coatings. ${ }^{[15-17]}$ Moreover, it is recognized that silica $\left(\mathrm{SiO}_{2}\right)$-based sol-gel systems usually have a high content of surface silanol groups, which have been reported to promote in vitro and in vivo nucleation of apatite. ${ }^{[18,19]}$ Galliano et al. ${ }^{[20]}$ reported that the silica films deposited on 316L SS substrate were able to reduce both the corrosion attack on the steel and the iron diffusion to the sample surface. However, not much study has been reported on the effect of silica-coated $316 \mathrm{~L} \mathrm{SS}$ on the structure, mechanical, and electrochemical behavior of the $\mathrm{TiO}_{2}$-reinforced hydroxyapatite coatings $\left(\mathrm{TiO}_{2} / \mathrm{HAP}\right)$. Therefore, the objective of the current study is to investigate the hydrophilic properties of $\mathrm{SiO}_{2}$ film, which can improve the bonding capability of the $\mathrm{TiO}_{2} / \mathrm{HAP}$ layer with the substrate and provide a first barrier against corrosion of the 316L SS in simulated human body fluids. Further, nanoindentation test is performed using the continuous stiffness measurement (CSM) mode in order to determine the 
variation of the hardness and elastic modulus of the coatings as a function of the indenter displacement.

Finally, the addition of titania phase into HAP and the use of silica as a bonding oxide layer between the $\mathrm{TiO}_{2} / \mathrm{HAP}$ top layer and the substrate are studied within the objective to improve the mechanical properties, bonding strength, and corrosion resistance of the hydroxyapatite- $\mathrm{TiO}_{2}-\mathrm{SiO}_{2}$-coated $316 \mathrm{~L} \mathrm{SS}$ system.

\section{MATERIALS AND METHODS}

\section{A. Experimental Details}

Tetraethyl orthosilicate (TEOS, Fluka 98 pct) was mixed with methyltriethoxysilane (MTES, Fluka 98 pct) in equimolar ratio. Hydrochloric acid $(0.1 \mathrm{~N})$ and acetic acid (HOAc) were added as catalysts, and their role is to increase the hydrolysis and condensation. The reaction rate to the concentrations of the chemical species present in the reaction mixture $\left(\mathrm{H}_{2} \mathrm{O}+\mathrm{HOAc}\right) /$ (TEOS + MTES) was 1.7. ${ }^{[2]}$ After stirring the solution under room temperature conditions for 24 hours, a transparent viscous sol was obtained. Precursor solution for HAP coating was prepared by dissolving phosphorous pentoxide $\left(\mathrm{P}_{2} \mathrm{O}_{5}\right.$, Prolabo $\left.100 \mathrm{pct}\right)(0.5 \mathrm{~mol} / \mathrm{l})$ and calcium nitrate tetrahydrate $\left(\mathrm{Ca}\left(\mathrm{NO}_{3}\right)_{2} \cdot 4 \mathrm{H}_{2} \mathrm{O}\right.$, Fluka 98 pct) $(1.67 \mathrm{~mol} / \mathrm{l})$ in absolute ethanol, ${ }^{[21]}$ and then the two solutions were mixed and continuously stirred for 24 hours at room temperature. Titanium isopropoxide (TIP, Fluka $100 \mathrm{pct}$ ) was used as a titania precursor. The reactivity towards water is modified by acetic acid (molar ratio of TIP $/ \mathrm{HOAc}=1 / 10$ ) which is also used as catalyst. 2-methoxy ethanol was added to adjust the viscosity of the solution. ${ }^{[22]}$ This solution was vigorously stirred under room temperature conditions. For the preparation of the composite sols, HAP and $\mathrm{TiO}_{2}$ solutions were mixed with different volumes: 0,20 , and 50 vol pet $\mathrm{TiO}_{2}$, and then the solutions were continuously stirred for 14 hours.

The 316L SS used as the substrates with dimensions of $20 \times 10 \times 5 \mathrm{~mm}$ was mechanically polished using different silicon carbide grit papers from 120 to 1200 grades. A mirror polishing was done using diamond paste of 2 and of $0.7 \mu \mathrm{m}$ in the final step. The substrates were ultrasonically degreased with acetone and washed with running double-distilled water, and then they were dried at $423 \mathrm{~K}\left(150{ }^{\circ} \mathrm{C}\right)$ for 10 minutes.

Table I. The Composition of SBF Solution at $310 \mathrm{~K}\left(37^{\circ} \mathrm{C}\right)$

\begin{tabular}{lll}
\hline Order & \multicolumn{1}{c}{ Reagent } & \multicolumn{1}{c}{ Amount } \\
\hline 1 & $\mathrm{NaCl}$ & $7.996 \mathrm{~g}$ \\
2 & $\mathrm{NaHCO}$ & $0.350 \mathrm{~g}$ \\
3 & $\mathrm{KCl}$ & $0.224 \mathrm{~g}$ \\
4 & $\mathrm{~K}_{2} \mathrm{HPO}_{4} \cdot 3 \mathrm{H}_{2} \mathrm{O}$ & $0.228 \mathrm{~g}$ \\
5 & $\mathrm{MgCl}_{2} \cdot 6 \mathrm{H}_{2} \mathrm{O}$ & $0.305 \mathrm{~g}$ \\
6 & $\mathrm{CaCl}_{2}$ & $0.278 \mathrm{~g}$ \\
7 & $\mathrm{Na}_{2} \mathrm{SO}_{4}$ & $0.071 \mathrm{~g}$ \\
8 & $\left(\mathrm{CH}_{2} \mathrm{OH}\right)_{3} \mathrm{CNH}_{2}$ (Tris) & $6.057 \mathrm{~g}$ \\
9 & $\mathrm{HCl}(1 \mathrm{M})$ & appropriate amount for \\
& & adjusting pH (pH 7.42) \\
\hline
\end{tabular}

Finally, the substrates were immersed in the HAP and $\mathrm{TiO}_{2} / \mathrm{HAP}$ sols and dipped in the suspensions at a speed of $80 \mathrm{~mm} / \mathrm{min}$, and then dried and annealed at $773 \mathrm{~K}$ $\left(500{ }^{\circ} \mathrm{C}\right)$ for 60 minutes. The obtained coatings are referenced as follows: $20 \mathrm{vol}$ pct $\mathrm{TiO}_{2}$ (H80T20), $50 \mathrm{vol}$ pet $\mathrm{TiO}_{2}$ (H50T50). The $\mathrm{SiO}_{2}$ layer was coated on the surface of the substrate at a speed of $100 \mathrm{~mm} / \mathrm{min}$, and then dried and annealed at $773 \mathrm{~K}\left(500{ }^{\circ} \mathrm{C}\right)$ for 60 minutes. The pure HAP and composite $\mathrm{HAP} / \mathrm{TiO}_{2}$ sols were subsequently dip-coated on the outer surface of the $\mathrm{SiO}_{2}$ film at a speed of $80 \mathrm{~mm} / \mathrm{min}$ and annealed at 773 $\mathrm{K}\left(500{ }^{\circ} \mathrm{C}\right)$ for 60 minutes. The obtained coatings are referenced as follows: $0 \mathrm{vol}$ pct $\mathrm{TiO}_{2}\left(\mathrm{HAP}-\mathrm{SiO}_{2}\right), 20 \mathrm{vol}$ pet $\mathrm{TiO}_{2}$ (H80T20-S), and 50 vol pet $\mathrm{TiO}_{2}$ (H50T50-S). In addition, pure $\mathrm{TiO}_{2}$ film was prepared by dipping at a speed of $20 \mathrm{~mm} / \mathrm{min}$, and then dried and annealed at 723 $\mathrm{K}\left(450{ }^{\circ} \mathrm{C}\right)$ for 60 minutes. ${ }^{[14]}$

\section{B. Characterizations}

The chemical states of the coatings were characterized by X-ray photoelectron spectroscopy (XPS) with a Thermo L-alpha spectrometer, using monochromatized $\mathrm{Al}-\mathrm{K} \alpha$ radiation as the excitation source $(h v=1486.6$ $\mathrm{eV}$ ), collected at $0 \mathrm{deg}$ from the surface normal, and detected with a hemispherical analyzer. The spot size of the XPS source on the sample was about $200 \mu \mathrm{m}$, and the pass energy was set of $20 \mathrm{eV}$. During data acquisition pressure was kept below $1 \times 10^{-9}$ Torr. Spectra were fitted using a 10 pct linear combination of Gaussian and Lorentzian profiles. Peak positions obtained after analysis were found essentially constant $( \pm 0.3 \mathrm{eV})$.

Water contact angles were obtained with a Digidrop Contact Angle Meter (GBX Surface Science Technologies). Measurements were carried out with $3 \mu$ d drops of ultra-pure water under ambient atmospheric conditions. Three drops were applied on each sample at different locations, to assure reproducibility and reliability of results.

Both the coating thickness and roughness were measured using a profilometry analysis "DEKTAK 150 SURFACE PROFILERT" by recording the surface profile of coated and uncoated regions over a single measurement run. The surface of the coating was scanned at an interval of 1000 to $8000 \mu \mathrm{m}$. Three different areas were scanned and measured to determine a mean value for the thickness and the roughness parameters.

The surface morphology of the samples was observed with a scanning electron microscope (SEM) (JSM-5400LV, JEOL) operating at 0 to $30 \mathrm{kV}$, associated with an ultra-thin window $\mathrm{Si}(\mathrm{Li})$ detector for the energy-dispersive X-ray measurements (EDX) (GENESIS, Eloïse SARL).

The different phases of the coatings were analyzed by X-ray diffraction Expert Prof Panalytical type MPD/ system vertical $\theta / \theta$, using radiation source $(\mathrm{Cu}-\mathrm{K} \alpha=$ $1.5406 \AA$ A) operating at $40 \mathrm{kV}$ and $30 \mathrm{~mA}$. The XRD diffraction patterns were collected over a $2 \theta$ range located between 20 and 80 deg using an incremental step size of $0.02 \mathrm{deg}$ with 6 seconds of acquisition time per 


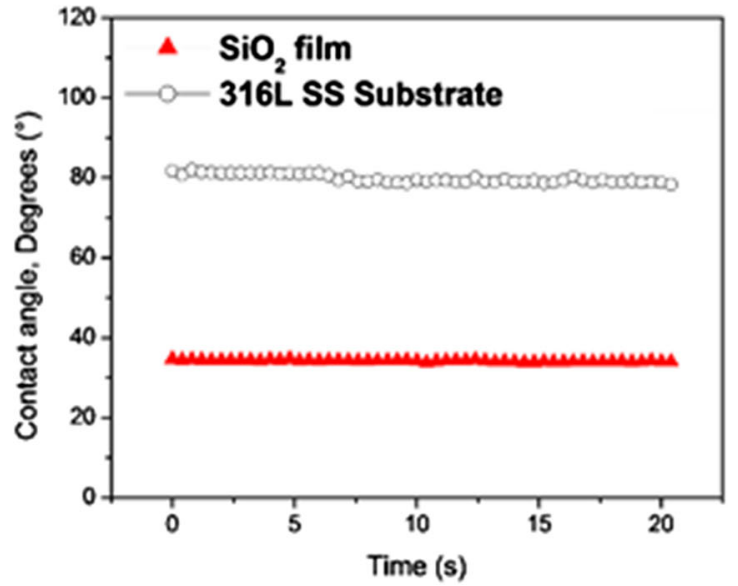

(a)

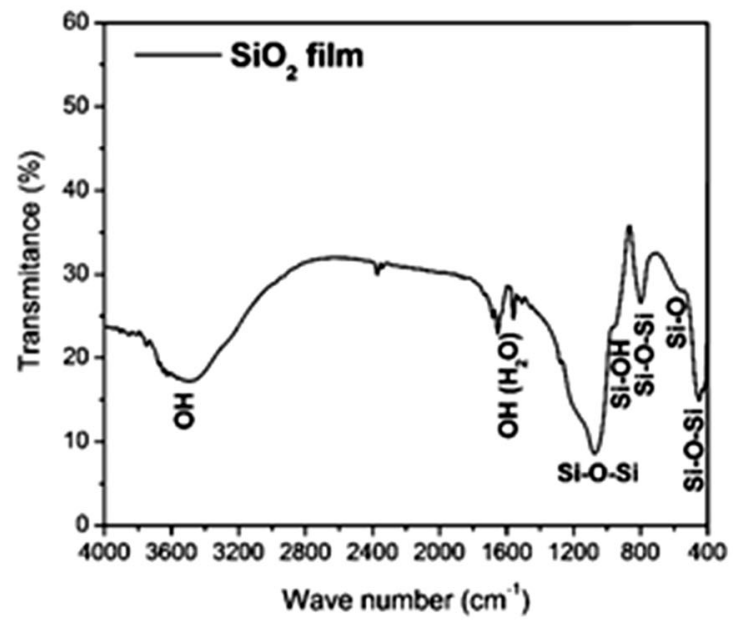

(c)

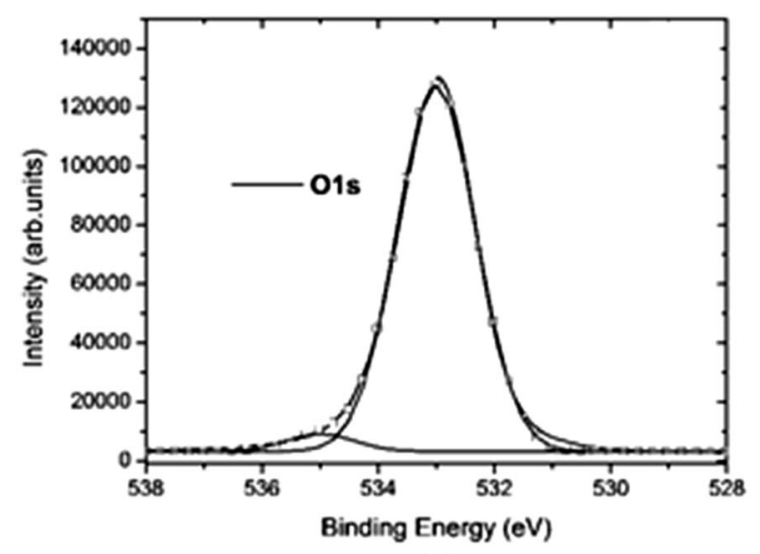

(e)

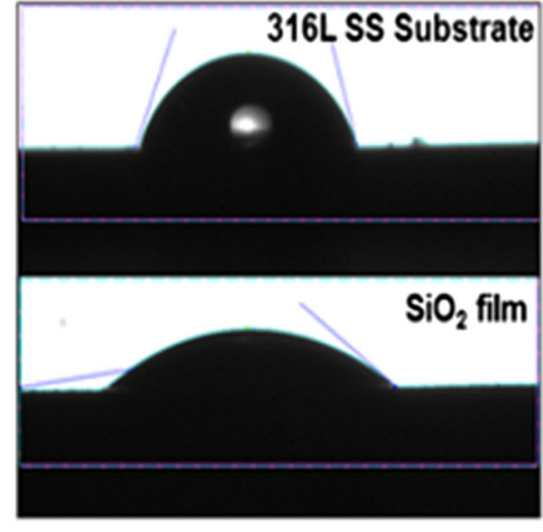

(b)

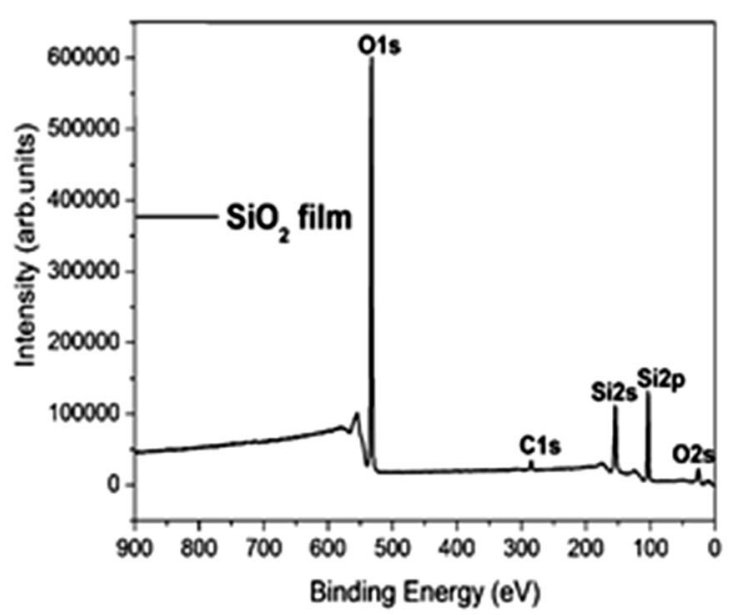

(d)

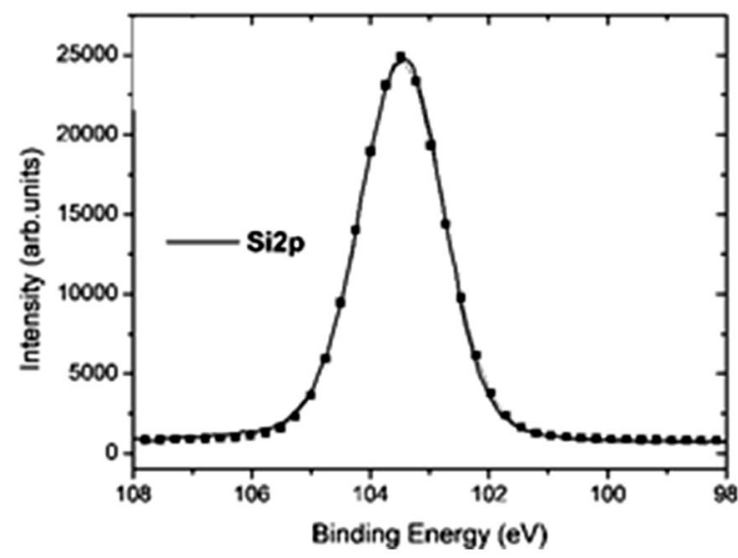

(f)

Fig. 1- (a) Contact angle between water, $\mathrm{SiO}_{2}$ oxide film, and 316L stainless steel substrate, $(b)$ Images of water droplets on the surfaces of the substrate and $\mathrm{SiO}_{2}$ film obtained after $20 \mathrm{~s}(c)$ FTIR spectrum of the single $\mathrm{SiO}_{2}$ film, (d) XPS spectrum of the single $\mathrm{SiO}{ }_{2}$ film, $(e, f)$ The spectra of $\mathrm{O} 1 \mathrm{~s}$ and Si2p, respectively.

step. The phase identification was performed by comparing the experimental XRD patterns to standards compiled by the International Center for Diffraction Data-Powder Diffraction Files (ICDD-PDF). Data were treated with Software X'Pert HighScore. The HAP and $\mathrm{TiO}_{2} / \mathrm{HAP}$ average crystallite sizes (L) were estimated with broadening XRD peaks using Debye-Scherrer equation: 

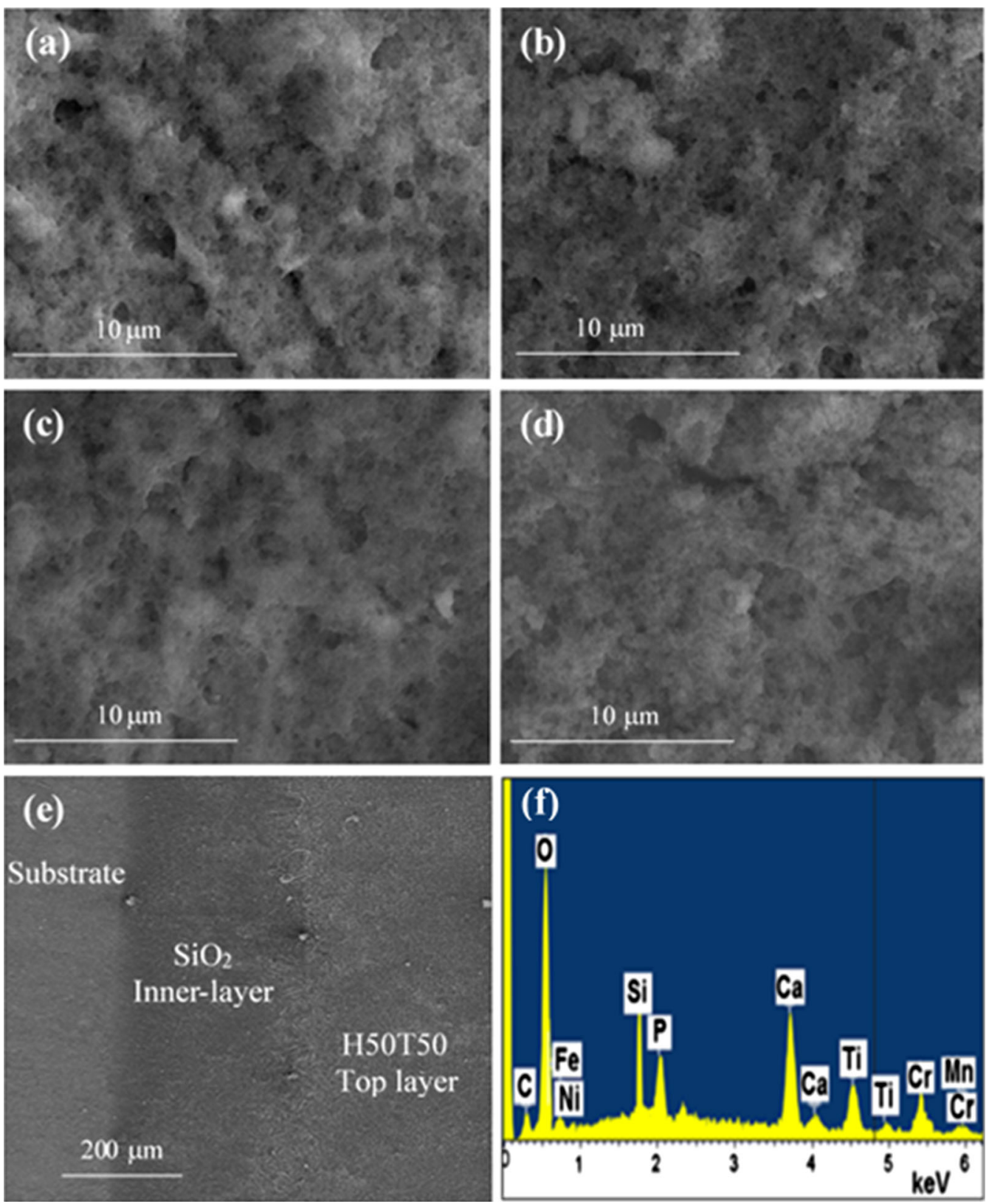

Fig. 2-SEM observations corresponding to (a) H80T20, (b) H50T50, (c) H80T20-S, and (d) H50T50-S coatings, (e) 316L SS substrate- $\mathrm{SiO}_{2}-\mathrm{H} 50 \mathrm{~T} 50$ interfaces, $(f)$ EDX elemental analysis.

Table II. Structural Parameters of the Uncoated and Coated 316L SS

\begin{tabular}{lcc}
\hline Sample & Thickness $(\mathrm{nm})$ & Roughness $(\mathrm{nm})$ \\
\hline 316L SS & - & 20 \\
HAP & 1600 & 1310 \\
HAP-SiO $_{2}$ & 1610 & 921 \\
H80T20 & 1336 & 740 \\
H80T20-S & 1544 & 642 \\
H50T50 & 1110 & 681 \\
H50T50-S & 1310 & 550 \\
\hline
\end{tabular}

$$
L_{\mathrm{hkl}}=\frac{K \lambda}{\beta \cos \theta},
$$

where $\lambda$ is the wavelength of the $\mathrm{Cu}-\mathrm{K} \alpha$ radiation, $\beta$ is full width at middle height (the Bragg peak maximum intensity (deg)), $\theta$ is Bragg's angle (deg), and $K$ is the Scherrer constant (equal to 0.9 when the width is measured at middle height of the diffraction peak). The mean crystallite size for pure HAP sample was calculated from the $\left(\begin{array}{lll}2 & 1 & 1\end{array}\right)$ reflection peak.

The structural analysis was carried out using the Fourier transform infrared (FTIR) spectrophotometer 


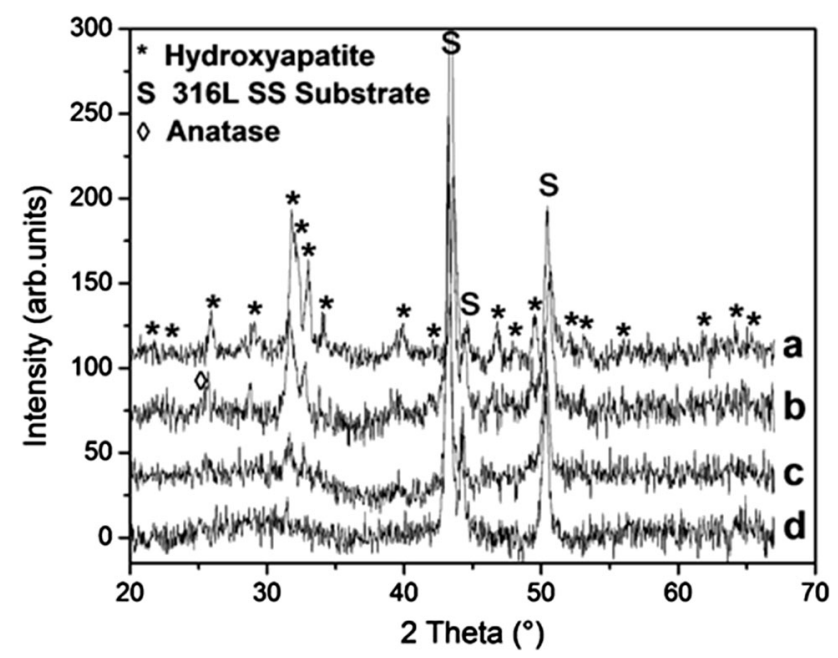

Fig. 3-XRD patterns of the (a) HAP, (b) H80T20, (c) H50T50, and (d) H50T50-S coatings. (*) Hydroxyapatite, (S) Substrate, and $(\diamond)$ Anatase.

instrument (IRAffinity-1, SHIMADZU). FTIR spectra were recorded in the range of 400 to $4000 \mathrm{~cm}^{-1}$ with a resolution of $4 \mathrm{~cm}^{-1}$. The deposited films were scraped off as powders from the substrate and mixed with $\mathrm{KBr}$ powder ( 80 pct in weight), to form an infrared transparent pellet.

Corrosion behavior of the samples was evaluated by potentiodynamic cyclic voltammetry tests by Voltalab (Serial: 913V708/INT), interfaced with a computer, and loaded with VoltaMaster 4 software in simulated human body fluid (SBF) at $310 \pm 274 \mathrm{~K}\left(37 \pm 1{ }^{\circ} \mathrm{C}\right)$. The SBF solution was prepared using Kokubo and Takadama's formulation ${ }^{[23]}$ by dissolving reagent-grade $\mathrm{NaCl}$, $\mathrm{NaHCO}_{3}, \mathrm{KCl}, \mathrm{K}_{2} \mathrm{HPO}_{4} \cdot 3 \mathrm{H}_{2} \mathrm{O}, \mathrm{MgCl}_{2} \cdot 6 \mathrm{H}_{2} \mathrm{O}, \mathrm{CaCl}_{2}$, and $\mathrm{Na}_{2} \mathrm{SO}_{4}$ into distilled water $(1 \mathrm{~L})$ and buffered at $\mathrm{pH}$ 7.40 with $\left(\mathrm{CH}_{2} \mathrm{OH}\right)_{3} \mathrm{CNH}_{2}$ and $1 \mathrm{M} \mathrm{HCl}$ solution (Table I). Before conducting the corrosion studies, the specimens were immersed in SBF solution for 1 hour in order to stabilize the system. ${ }^{[14]}$ Moreover, a renewed solution was used for each experiment. The exposed area of the samples in the SBF solution was $1 \mathrm{~cm}^{2}$. A platinum electrode was used as the auxiliary electrode, and the saturated calomel electrode (SCE) was used as the reference electrode. Corrosion potential $\left(E_{\mathrm{Corr}}\right)$ and corrosion current density $\left(i_{\text {Corr }}\right)$ were determined using the Tafel diagram with sweeping potential from -1000 to $+1000 \mathrm{mV}$ at the rate of $1 \mathrm{mVs}^{-1}$, and at least three similar results were required to ensure reproducibility.

The adhesion of the coating was estimated using a scratch tester (Millennium in accord with Standard ISO/ EN 1071-3) with a spherical Rockwell C diamond indenter of $200 \mu \mathrm{m}$ in radius. The scratch tests were performed on the coating by applying the load, which increased monotonously at the loading rate of 10000 $\mathrm{mN} / \mathrm{min}$ while the specimen was shift at the constant speed of $1500 \mu \mathrm{m} / \mathrm{min}$. The applied force immediately started to increase linearly with time. These conditions lead to a total scratch length of $1500 \mu \mathrm{m}$. The load at which coating was removed from the substrate is referred as the critical load (Lc). The scratch track was
Table III. Crystalline and Lattice Parameters of HAP and $\mathrm{TiO}_{2} / \mathrm{HAP}$ Coatings

\begin{tabular}{llll}
\hline & HAP & H80T20 & H50T50 \\
\hline a (̊̊) & 9.410 & 9.394 & 9.392 \\
$\mathrm{c}(\AA)$ & 6.887 & 6.884 & 6.870 \\
$\mathrm{~L}_{211}(\mathrm{~nm})$ & 135 & 61.7 & 30.8 \\
\hline
\end{tabular}

observed using optical microscope. Five tests for each sample were recorded.

Nanoindentation experiments were performed with a Nano Indenter XP TM (MTS Nano Instruments) employing a Berkovich diamond indenter calibrated using a reference sample of known modulus (fused quartz, $E=72 \mathrm{GPa}$ ). The samples were fixed on a metallic support using the heat softening glue crystalbond 509. A regular array of $5 \times 5$ indentation tests has been performed at the surface of the different coated materials in order to obtain representative variations of the hardness and the elastic modulus as a function of the indenter displacement. The maximum indentation depth reached by the indenter was fixed at $2000 \mathrm{~nm}$ and the strain rate was set constant and equal to $0.05 \mathrm{~s}^{-1}$. The instrument was operated in the continuous stiffness measurement (CSM) mode allowing the computation of the elastic modulus and the hardness continuously during the indentation loading. The harmonic displacement was $2000 \mathrm{~nm}$ and the frequency was $45 \mathrm{~Hz}$. The elastic modulus of the coating, $\mathrm{E}_{\mathrm{C}}$, is deduced from the reduced modulus, $E_{\mathrm{RC}}$, given by the instrument, which takes into account the elastic properties, $E_{\mathrm{i}}$ and $v_{\mathrm{i}}$, related to the indenter material and the Poisson's ratio of the coating, $v_{\mathrm{c}}$ :

$$
E_{\mathrm{C}}=\left(1-v_{\mathrm{C}}^{2}\right)\left[\frac{1}{E_{\mathrm{RC}}}+\frac{\left(1-v_{i}^{2}\right)}{E_{i}}\right]^{-1} .
$$

For a diamond indenter, the elastic modulus, $E_{\mathrm{i}}$, and the Poisson's coefficient, $v_{\mathrm{i}}$, are equal to $1140 \mathrm{GPa}$ and 0.07 , respectively. ${ }^{[24]} v_{\mathrm{c}}$ is taken equal to the mean value of 0.3 because the analysis deals with a multilayered coating.

\section{RESULTS AND DISCUSSION}

\section{A. Hydrophilic Properties of $\mathrm{SiO}_{2}$ Surface}

The effect of the $\mathrm{SiO}_{2}$ film on the hydrophilic properties of the $316 \mathrm{~L}$ SS samples was evaluated by measuring their water contact angles (Figures 1(a) and (b)). Contact angle variations are compared to those measured on the as-prepared 316L SS substrate, i.e., polished and degreased, then dried at $423 \mathrm{~K}\left(150{ }^{\circ} \mathrm{C}\right)$, and those measured on the $\mathrm{SiO}_{2}$ single-layer-coated $316 \mathrm{~L} \mathrm{SS}$. All the specimens were aged for 60 days in the ambient environment. As shown in Figure 1(a), the contact angle does not vary with time indicating that the shape and/or the size of the water drop applied on the supports did not vary with time during the measurement. The representative images of the water droplets deposited on the substrate and $\mathrm{SiO}_{2}$ film surfaces are 


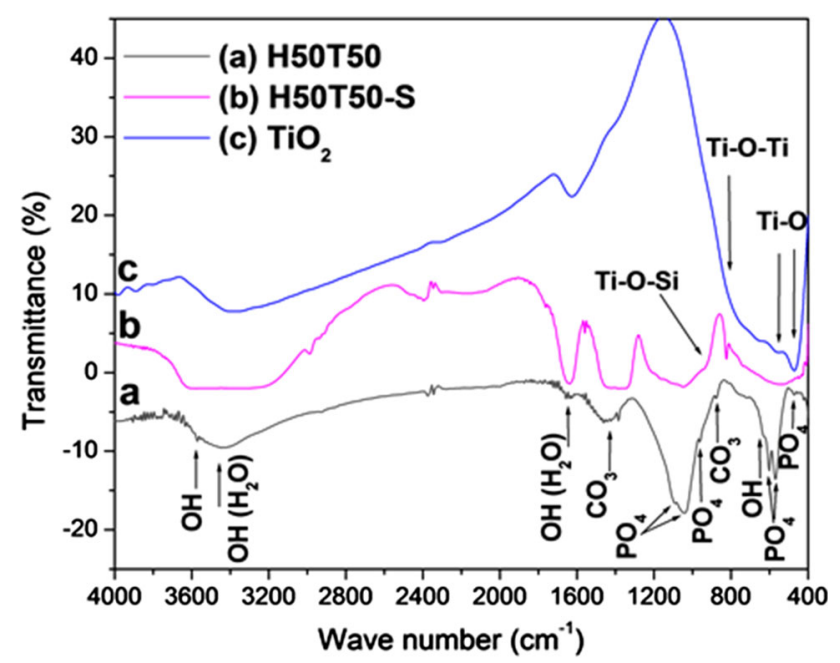

Fig. 4-FTIR spectra of the (a) H50T50, (b) H50T50-S coatings, and (c) $\mathrm{TiO}_{2}$ film.

presented in Figure 1b. The contact angle measurements indicate that the substrate is partially wetted by water and that wettability of the steel is the lowest, the $316 \mathrm{~L}$ steel substrate has contact angle of $79.8 \pm 0.1 \mathrm{deg}$, water wets silica rather well than the substrate, and it represents a contact angle of $34.2 \pm 0.02 \mathrm{deg}$. These results are in agreement with the previous works of Houmard et al. ${ }^{[25]}$ and Permpoon et al. ${ }^{[26]}$ showing that silica films prepared by sol-gel method and heat-treated at $773 \mathrm{~K}\left(500{ }^{\circ} \mathrm{C}\right)$ continuously exhibited a very slow contact angle increase over a period of 60 days aging, which confirms the natural hydrophilicity of a silica surface due to the hydroxyl content on the film surface.

FTIR analyses performed on the same films after 60 days aging are represented in Figure 1(c). There is a broad band in the range of 3200 to $3800 \mathrm{~cm}^{-1}$ corresponding to stretching vibration of different hydroxyl groups associated to absorbed free water and to $\mathrm{Si}-\mathrm{OH}$ (silanols) groups linked to molecular water through hydrogen bonds as well as isolated free surface silanols. The bands around 1556 and $1656 \mathrm{~cm}^{-1}$ correspond to bending vibrations of $\mathrm{OH}$ bonds of water molecules. The band around $565 \mathrm{~cm}^{-1}$ is attributed to $\mathrm{Si}-\mathrm{O}$ bonds in an amorphous phase. The bands at 460 , $800 \mathrm{~cm}^{-1}$, and in the range of $1000-1220 \mathrm{~cm}^{-1}$ are attributed to the bond bending and bond stretching vibrations of the Si-O-Si units in silica. The band at 935 $\mathrm{cm}^{-1}$ is assigned to the stretching vibration of a small amount of Si-OH groups. ${ }^{[27-29]}$

Figure 1(d) related to the XPS spectrum shows the elemental composition of deposited $\mathrm{SiO}_{2}$ film. The binding energy peaks are corresponding to $\mathrm{Si} 2 \mathrm{~s}, \mathrm{Si} 2 \mathrm{p}$, and $\mathrm{O} 1 \mathrm{~s}$ of $\mathrm{SiO}_{2}$ film. It is inferred that the $\mathrm{C} 1 \mathrm{~s}$ peak at $284.7 \mathrm{eV}$ essentially reflects the amount of carbon contamination at the outer surface. Previous studies $^{[26,30]}$ have shown that alkoxy groups, which might contribute to the $\mathrm{C}$ ls peak, are not present in $\mathrm{SiO}_{2}$ film heated at $500{ }^{\circ} \mathrm{C}$, and alkoxy groups arising from the silica precursors are completely decomposed after annealing at $773 \mathrm{~K}\left(500{ }^{\circ} \mathrm{C}\right)$. In addition, XPS analysis was used to investigate the surface hydrophilic properties of $\mathrm{SiO}_{2}$ film. The presence of $\mathrm{OH}$ groups on the $\mathrm{SiO}_{2}$ outer surface is studied from the deconvolution of the Ols peak. The O1s peak could be decomposed in two components, i.e., $\mathrm{Si}-\mathrm{OH}$ and $\mathrm{Si}-\mathrm{O}$ components, using Lorentzian/Gaussian functions (Figures 1(e) and (f)). The O-H component essentially traduces the presence of surface hydroxyl groups; the Ols region includes two peaks (Figure 1(e)). One component of the O1s peak is attributed to the $\mathrm{Si}-\mathrm{O}(533 \mathrm{eV})$ and the other one is assigned to the hydroxyl group Si-OH (535 eV). Binding energies of these components were subsequently compared to those of component measured for pure $\mathrm{SiO}_{2}$ film. ${ }^{[26]}$ The hydroxyl content (pct) is the ratio of the area of $535 \mathrm{eV}$ component to the total area of the two Ols components. The hydroxyl content for $\mathrm{SiO}_{2}$ film was calculated as 4 pct. This observation is in accordance with FTIR results, which depicted an amount of surface $\mathrm{OH}$ groups for the $\mathrm{SiO}_{2}$ layer. The deconvolution of the $\mathrm{Si} 2 \mathrm{p}$ spectrum into a single $\mathrm{Si}^{4+}$ component located at $103.5 \mathrm{eV}$ is presented in Figure 1(f), and the location of this component is very similar to that measured for pure $\mathrm{SiO}_{2}$ film. ${ }^{[31]}$

\section{B. Morphological and Structural Characterization of Sol-Gel-Derived Hydroxyapatite Coatings}

Figure 2 shows the surface of the $\mathrm{HAP} / \mathrm{TiO}_{2}$ deposited on the $\mathrm{SiO}_{2}$-coated and uncoated $316 \mathrm{~L} \mathrm{SS}$ substrates. The images show highly intermixed composite phases. From Figure 2(c) and (d), it can be seen that H80T20-S and H50T50-S have the continuous and regular microstructure. Moreover, the deposits cover entire surface of the substrate compared to H80T20 (Figure 2(a)) and H50T50 (Figure 2(b)). Figure 2(e) illustrates the SEM micrograph of the H50T50 top layer $/ \mathrm{SiO}_{2}$ inner layer/substrate interfaces. Some microcracks are generated in the coating, which can represent the interface separating the H50T50 and $\mathrm{SiO}_{2}$ layers; otherwise the deposit is mostly uniform throughout the rest areas, and no delamination was observed. The EDX spectrum obtained on the H50T50-S coating indicates the peaks corresponding to the elements that are originating from the substrate, $\mathrm{HAP}, \mathrm{TiO}_{2}$, and $\mathrm{SiO}_{2}$ phases; in addition, carbon element was detected.

The thickness and roughness of the sol-gel-derived coatings are collected in Table II. All the coatings presented a thickness less than $2 \mu \mathrm{m}$. Pure HAP coating exhibited a higher surface roughness $(\simeq 1310 \mathrm{~nm})$. The addition of both $\mathrm{TiO}_{2}$ and $\mathrm{SiO}_{2}$ decreased the roughness of the coatings up to $550 \mathrm{~nm}$. According to Sidane et al., ${ }^{[32]}$ the SEM surface examination of the HAP coating exhibited a porous surface composed of spherical agglomerates. After the addition of $\mathrm{TiO}_{2}$ into HAP phase, it can be seen that H80T20 (Figure 2(a)) and H50T50 (Figure 2(b)) composite coatings have regular surface. The porosity and the agglomerated particles are reduced and almost disappeared after the insertion of $\mathrm{SiO}_{2}$ inner layer between the composite top layer and the substrate, so the resulted H80T20-S and H50T50-S bilayer coatings have the uniform surface as it is shown in Figures 2(c) and (d). 

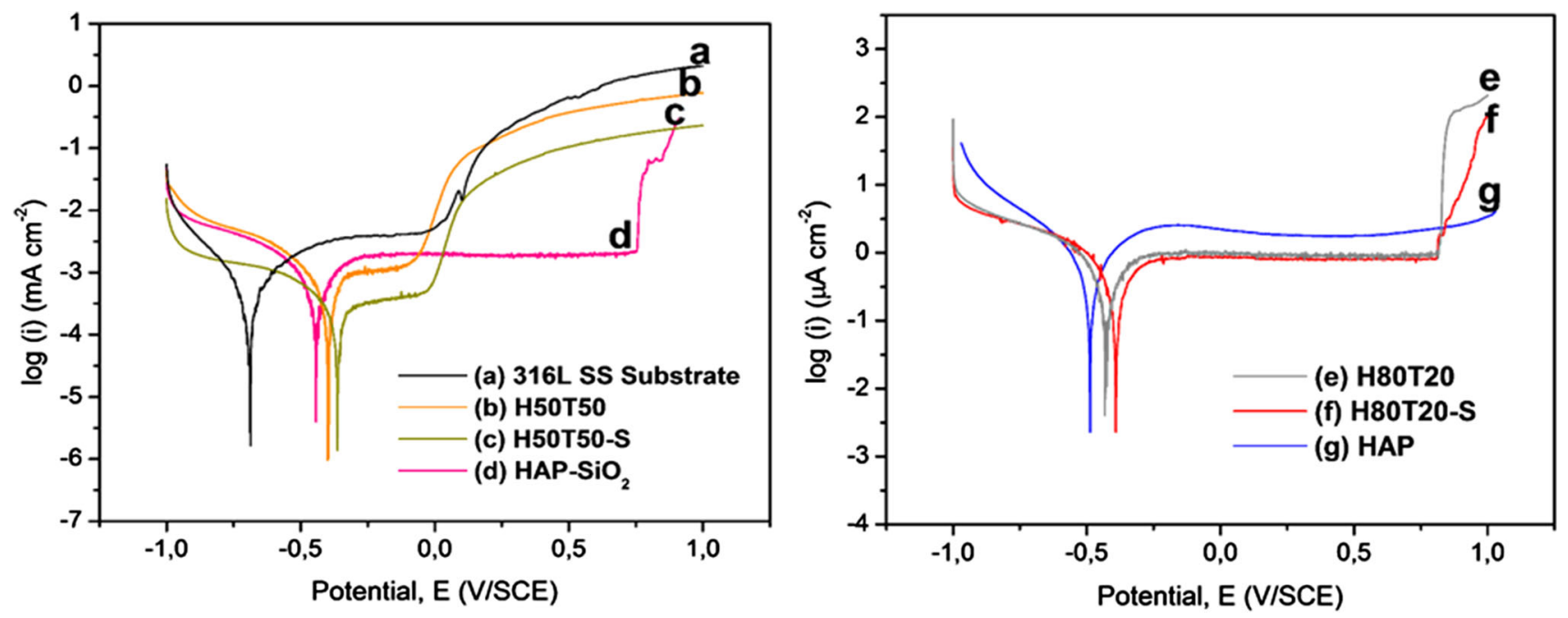

Fig. 5-Potentiodynamic curves of (a) the uncoated 316L stainless steel substrate (b) H50T50, (c) H50T50-S, (d) HAP-SiO 2 , (e) H80T20, (f) H80T20-S, and (g) HAP coatings in SBF solution at $310 \mathrm{~K}\left(37^{\circ} \mathrm{C}\right)$.

Table IV. Corrosion and Scratch Test Parameters of the Uncoated and Coated 316L SS

\begin{tabular}{|c|c|c|c|c|}
\hline \multirow[b]{2}{*}{ Sample } & \multicolumn{2}{|c|}{ Corrosion Test } & \multicolumn{2}{|c|}{ Scratch Test } \\
\hline & $E_{\text {Corr }}(\mathrm{mV})$ & $i_{\text {Corr }}\left(\mu \mathrm{A} \mathrm{cm}^{-2}\right)$ & Scratch length $(\mu \mathrm{m})$ & Critical load, Lc $(\mathrm{mN})$ \\
\hline $316 \mathrm{~L} \mathrm{SS}$ & -690 & 1.120 & - & - \\
\hline HAP & -484 & 0.849 & - & - \\
\hline $\mathrm{HAP}-\mathrm{SiO}_{2}$ & -445 & 0.812 & - & - \\
\hline Н80T20 & -423 & 0.801 & 820 & 4820 \\
\hline H80T20-S & -383 & 0.724 & 880 & 4980 \\
\hline H50T50 & -395 & 0.758 & 900 & 5050 \\
\hline H50T50-S & -362 & 0.251 & 980 & 5680 \\
\hline
\end{tabular}

The composition and microstructure of the coatings were characterized by XRD analysis (Figure 3). According to the International Center for Diffraction Data (ICDD) patterns, the pattern of the HAP coating (Figure 3(a)) shows peak positions, which correspond to a crystallized HAP structure (PDF no. 09-0432). The HAP characteristic triplet peaks at (211), (112), and (300) planes are observed for $2 \theta$ values between 31 and $33 \mathrm{deg}$, and the peak at the plane (002) is observed for $2 \theta=25.88 \mathrm{deg}$. In addition to the existing HAP peaks, diffraction peaks corresponding to steel substrate (PDF no. 00-006-0694) are developed. Addition of $20 \mathrm{vol}$ pct $\mathrm{TiO}_{2}$ (Figure 3(b)) and 50 vol pct $\mathrm{TiO}_{2}$ (Figure 3(c)) shows almost similar diffraction pattern such as pure HAP, but the peaks become wider with a change in the position and a decrease in the intensity. The mean peak corresponding to the crystalline structure of anatase $(2 \theta=25.35 \mathrm{deg})$ (PDF no. 00-004-0477) is confused with that of HAP $(2 \theta=25.88 \mathrm{deg})$. When $\mathrm{TiO}_{2}$ concentration increases further, a peak shift and the decrease in the XRD peak intensity are observed. This confirms the previous results of Nathanael et al. ${ }^{[15,16]}$ who attributed the initial small decrease in the intensities of the HAP peaks to the small inclusion of $\mathrm{TiO}_{2}$ in HAP. There are different proposals in the literature for possible Ti substitution mechanisms in HAP structure.
According to Ergun et al. ${ }^{[33]}$ and Riberio et al. ${ }^{[34]}$ the ionic radius of $\mathrm{Ti}^{4+}(0.68 \AA)$ is much smaller than the ionic radius of $\mathrm{Ca}^{2+}(0.99 \AA)$, and then the substitution of $\mathrm{Ca}$ by low concentrations of $\mathrm{Ti}$ can be occurred and results in a decrease in the cell lattice parameters and crystal domain size. Therefore, lattice disorder increased with the increasing of $\mathrm{Ti}$ content. Thus, this lattice disorder greatly inhibits the crystallization and makes it difficult to obtain high crystallinity in HAP-modified structure. $^{[35]}$ Crystallite size and lattice parameters, calculated from diffraction line broadening, are regrouped in Table III. They decrease as the content of $\mathrm{TiO}_{2}$ increases from 20 to 50 vol pct, respectively. After the deposition of $\mathrm{SiO}_{2}$ inner layer on the $316 \mathrm{~L} \mathrm{SS}$ substrate, the pattern of H50T50-S (Figure 3(d)) reveals an important shift and reduction in the intensity of HAP peaks. This behavior could be related to a combination between the $\mathrm{SiO}_{2}, \mathrm{TiO}_{2}$, and $\mathrm{HAP}$ phases through chemical bonding. There is no crystalline phase of $\mathrm{SiO}_{2}$ detected by the X-rays diffraction because the microstructure of the $\mathrm{SiO}_{2}$ is amorphous. ${ }^{[32]}$

Figure 4 shows the FTIR spectra of the H50T50, H50T50-S, and pure $\mathrm{TiO}_{2}$ coatings. FTIR spectrum of H50T50 (Figure 4(a)) exhibits the well-defined bands associated with the presence of $\mathrm{PO}_{4}$ groups at 473, 563, $600,964,1049$, and $1089 \mathrm{~cm}^{-1}$. The broad and 


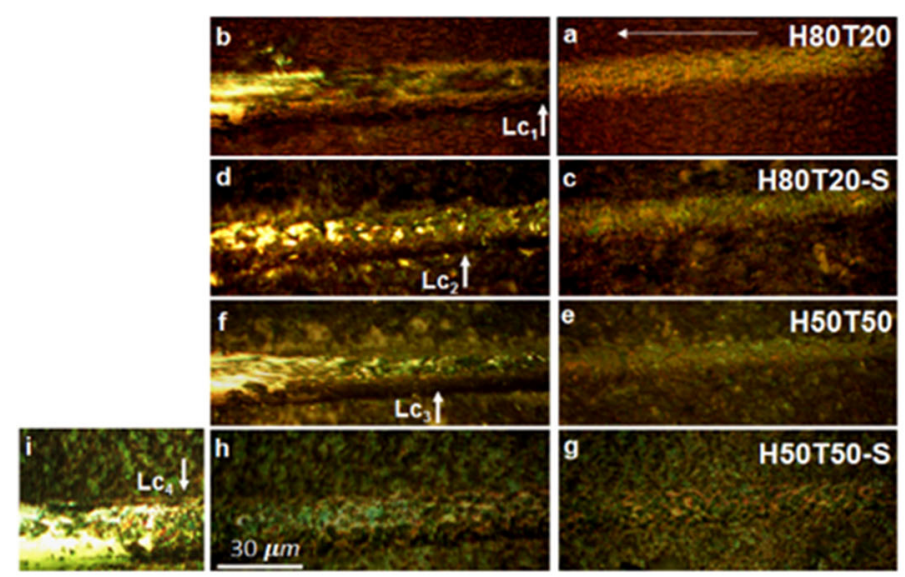

(A)

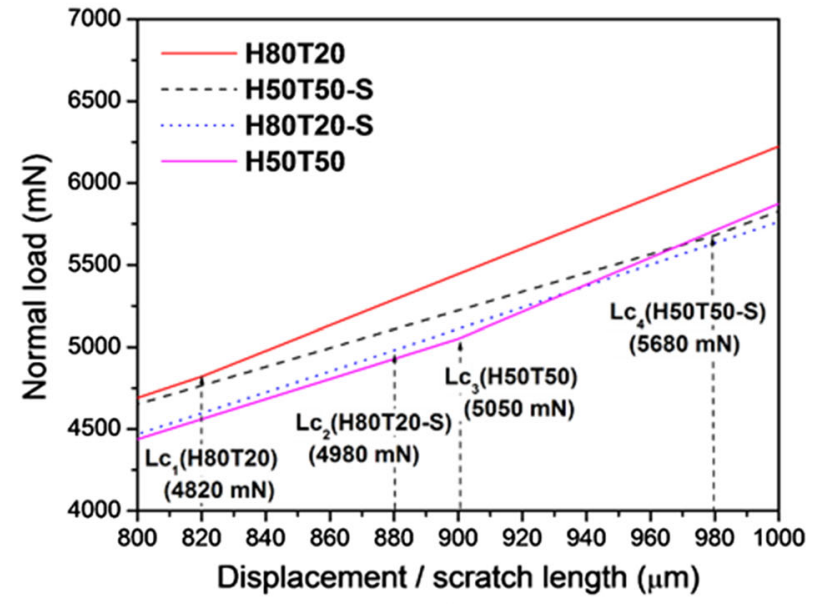

(B)

Fig. 6 - (A) Optical images representative of the scratch length realized on the surface of $(a, b)$ H80T20, $(c, d)$ H80T20-S, $(e, f)$ H50T50, and $(g$ through $i$ ) H50T50-S coatings; load is progressively increasing from right to left; (a), (c), (e), and (g) are related to the initial scratch. (B) Load-displacement graph corresponding to the scratch track presented in the (b, d, f, and h) optical images.

$\left(\mathrm{TiO}_{2} / \mathrm{HAP}\right)$ sol

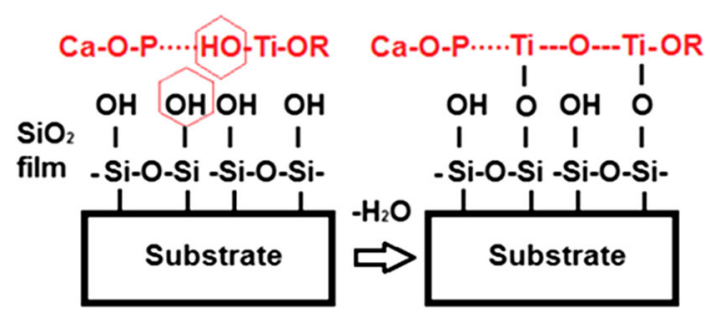

Fig. 7- Schematic diagrams revealing possible bonding mechanism of $\mathrm{TiO}_{2} / \mathrm{HAP}$ phases on the surface of $\mathrm{SiO}_{2}$ film during the immersion in mixed $\mathrm{TiO}_{2} / \mathrm{HAP}$ sol, through hydroxyl group association.

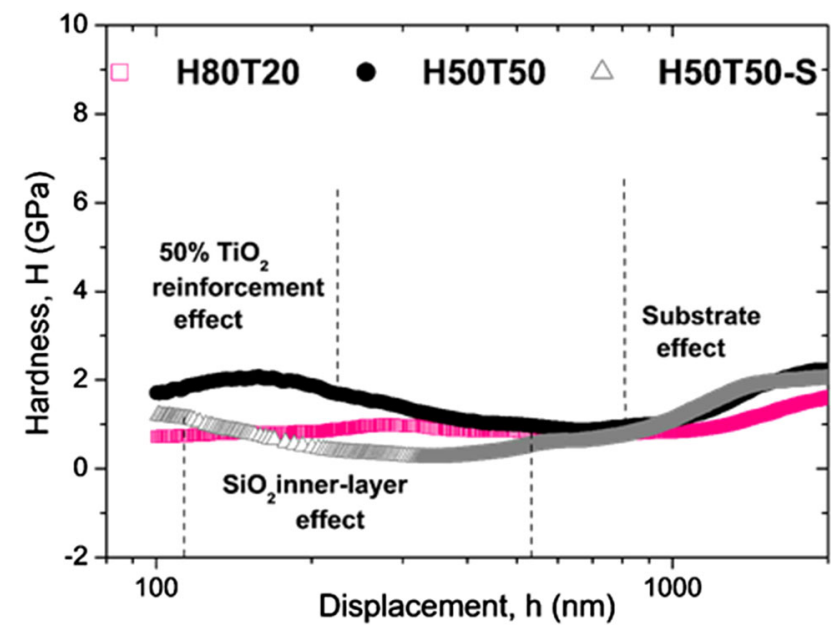

Fig. 8-Hardness $v s$ the indenter displacement performed on H80T20, H50T50, and H50T50-S coatings.

high-intensity band extending from 2500 to $3600 \mathrm{~cm}^{-1}$ and the band at $1632 \mathrm{~cm}^{-1}$ correspond to the hydrogen-bonded $\mathrm{H}_{2} \mathrm{O}$ molecules. The bands of $\mathrm{CO}_{3}^{2-}$ groups are indicated as a singlet at $873 \mathrm{~cm}^{-1}$ and in the range of
Table V. The Elastic Modulus and the Fitting Parameters of the $\mathrm{TIO}_{2} / \mathrm{HAP}$ Coatings

\begin{tabular}{|c|c|c|c|c|c|c|c|c|}
\hline & \multicolumn{4}{|c|}{ Perriot and Barthel } & \multicolumn{4}{|c|}{ Avrami } \\
\hline & $\begin{array}{c}E_{\mathrm{F}} \\
(\mathrm{GPa})\end{array}$ & $\begin{array}{c}E_{\mathrm{S}} \\
(\mathrm{GPa})\end{array}$ & $x_{0}$ & $n$ & $\begin{array}{c}E_{\mathrm{F}} \\
(\mathrm{GPa})\end{array}$ & $\begin{array}{c}E_{\mathrm{S}} \\
(\mathrm{GPa})\end{array}$ & $k_{\mathrm{s}}$ & $n_{\mathrm{s}}$ \\
\hline H80T20 & 19 & 176 & 3.5 & 2.24 & 21 & 177 & 21 & 2 \\
\hline H50T50 & 32 & 183 & 5 & 2.9 & 33 & 188 & 10.4 & 2.6 \\
\hline
\end{tabular}

1400 to $1540 \mathrm{~cm}^{-1}$. The origin of the carbonate bands is due to the absorption of atmospheric $\mathrm{CO}_{2}$ into the ethanol solution. ${ }^{[14,36]}$ In addition, the FTIR spectrum shows the vibrational bands related to the stretching vibration of Ti-O at 467 and $565 \mathrm{~cm}^{-1}$ and the asymmetric broad of Ti-O-Ti at about $810 \mathrm{~cm}^{-1}$ in the anatase phase of $\mathrm{TiO}_{2}$ lattice, as shown in Figure 4(c). ${ }^{[27]}$ An intensity decrease of the $\mathrm{OH}$ bands at 3572 and $630 \mathrm{~cm}^{-1}$ arising from the stretching and vibrational modes, respectively, of the $\mathrm{OH}^{-}$ions in the hydroxyapatite structure is noticed. These observations are in agreement with the results of XRD patterns. The librational mode of the $\mathrm{OH}$ group $\left(632 \mathrm{~cm}^{-1}\right)$ is especially sensitive to substitutions in the apatite structure. The strength of this peak is well known to correlate with the degree of crystallinity of HAP. In the presence of $\mathrm{Ti}$, the area of the $\mathrm{OH}$ librational band decreases, suggesting a decrease in HAP crystallinity, and consequently a decrease in crystallite size. The decrease in intensity of the $\mathrm{OH}$ peak at $3572 \mathrm{~cm}^{-1}$ is also indicative of changes in the HAP structure. ${ }^{[34]}$ After insertion of $\mathrm{SiO}_{2}$ inner layer, the FTIR spectrum of H50T50-S (Figure 4(b)) exhibits the bands corresponding with the presence of hydroxyapatite but their resolution decreases. The spectrum exhibits the broadening of absorption bands corresponding to phosphates, hydroxyls, and carbonates with the presence of well-developed bands related to Ti-O and Ti-O-Ti bonds. Indeed, the development of a weaker absorption peak of Ti-O-Si 


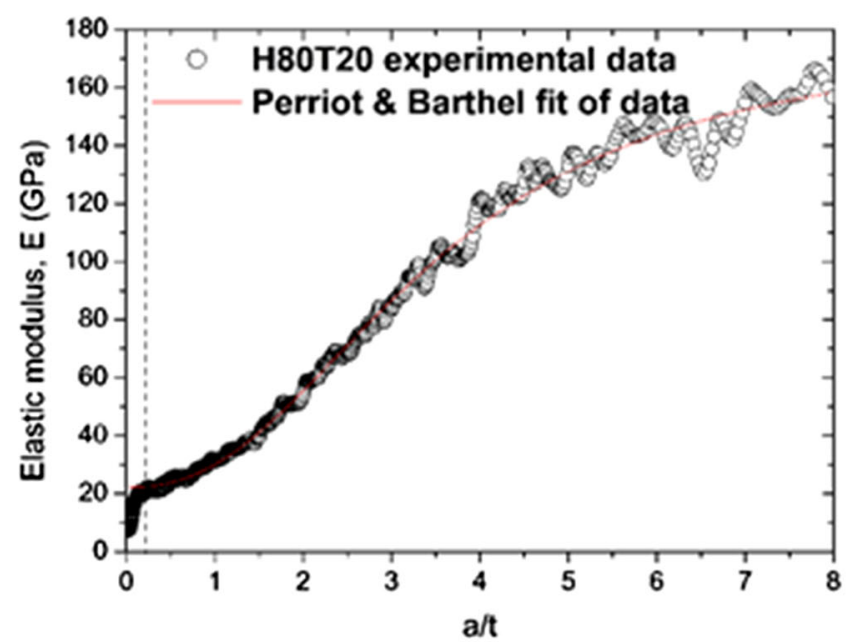

(a)

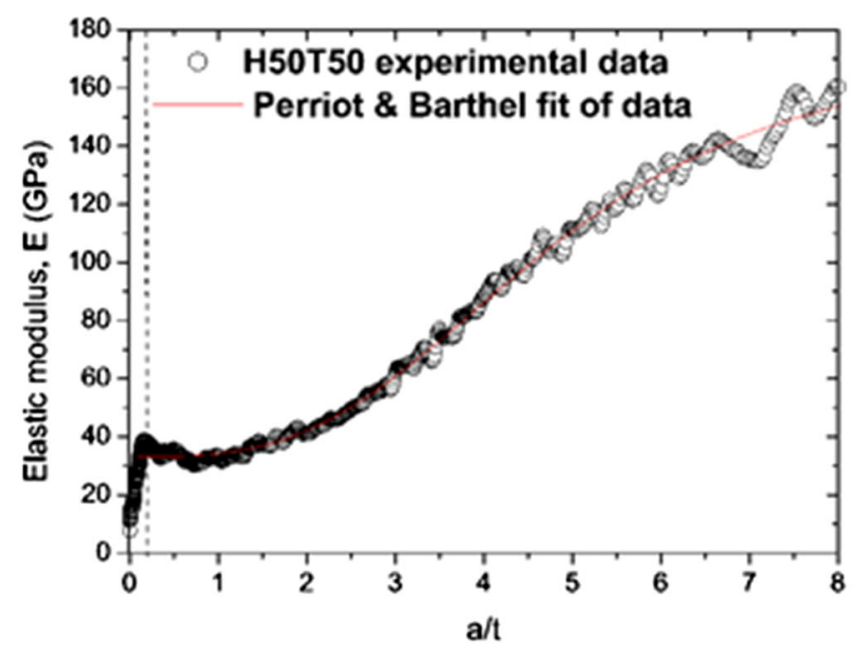

(c)

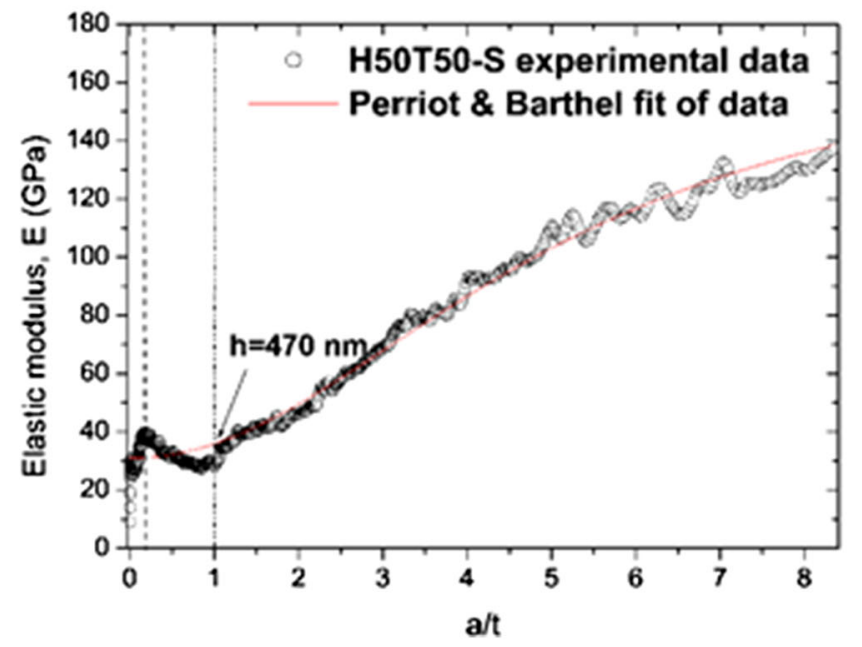

(e)

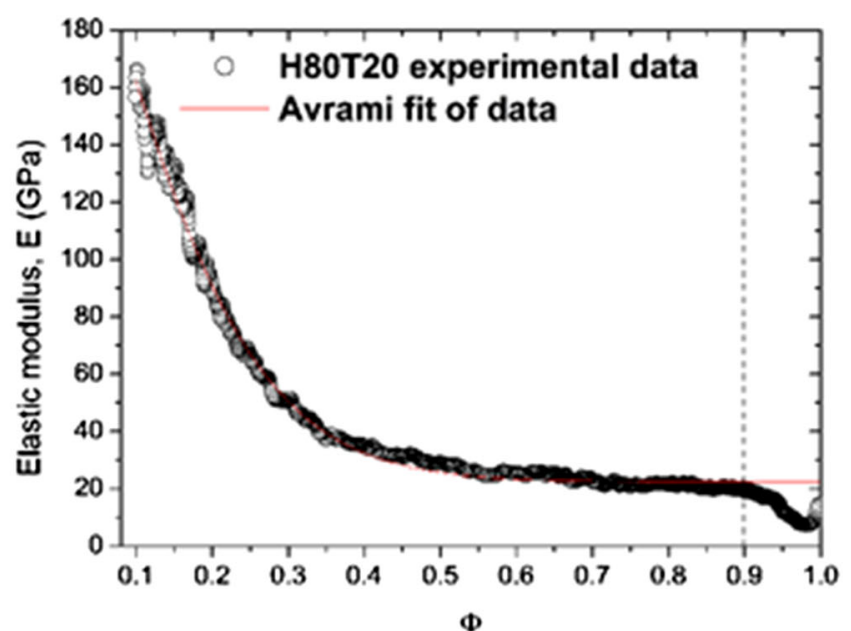

(b)

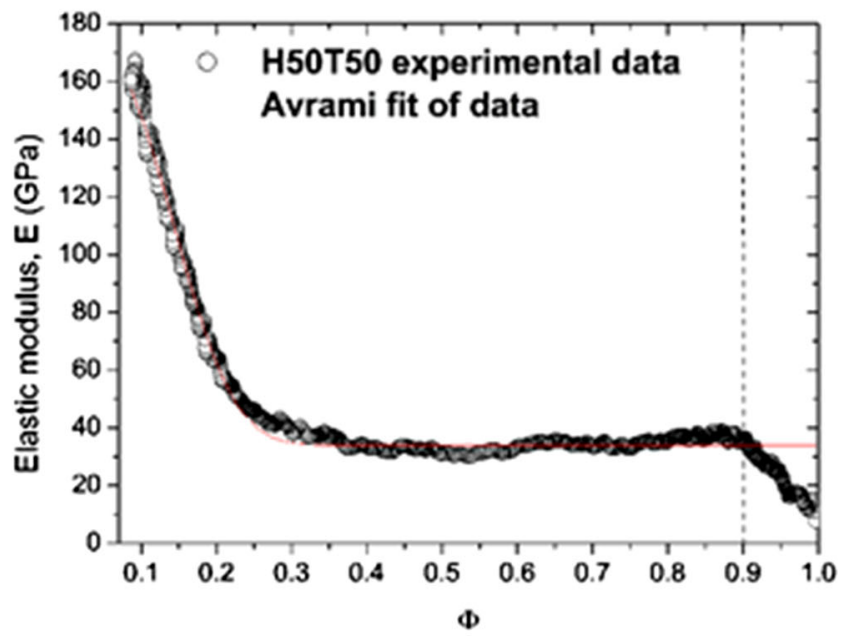

(d)

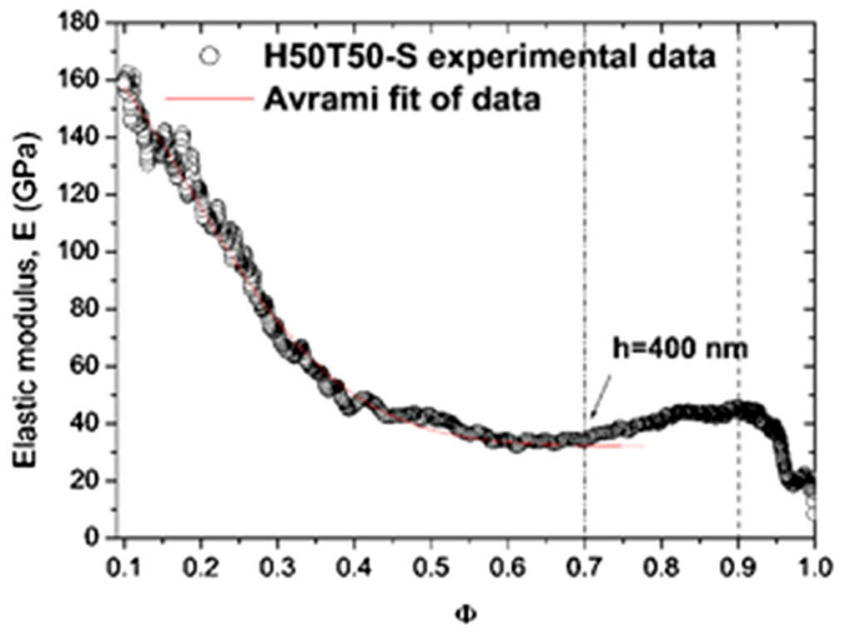

(f)

Fig. 9-Models applied on the indentation data obtained from nanoindentation test performed on $(a, b)$ H80T20, $(c, d)$ H50T50, and $(e, f)$ H50T50-S coatings. 
mixed bond at $925 \mathrm{~cm}^{-1}$ was observed, ${ }^{[27]}$ which demonstrates the Ti-O-Si bond formation due to the bonding of $\mathrm{Si}-\mathrm{OH}$ groups present on the surface of the $\mathrm{SiO}_{2}$ film underlying layer as shown in the previous section.

\section{Corrosion Resistance}

Figure 5 shows the potentiodynamic polarization plots of the coated and uncoated 316L SS substrate specimens immersed in SBF solution at $310 \pm 274 \mathrm{~K}$ (37 $\left.\pm 1{ }^{\circ} \mathrm{C}\right)$. Results of electrochemical tests revealed the influence of the different deposits on the corrosion resistance of the $316 \mathrm{~L}$ steel. The corrosion parameters determined from these curves by means of Tafel extrapolation method are summarized in Table IV. The corrosion parameters are corrosion potential $\left(E_{\mathrm{Corr}}\right)$ and corrosion current density $\left(i_{\text {Corr }}\right)$. For H50T50-S (Figure 5(c)) and H80T20-S (Figure 5(f)), the potentiodynamic curves were shifted to the right when compared to H50T50 (Figure 5(b)) and H80T20 (Figure 5(e)) curves, respectively. Representative potentiodynamic curve obtained for $\mathrm{HAP}-\mathrm{SiO}_{2}$ (Figure 5(d)) was shifted to the positive potential side compared to pure HAP (Figure 5(g)) and 316L SS sample (Figure 5(a)), respectively. The corrosion resistance of the specimens increases when decreasing $i_{\text {Corr }}$. For the substrate, $i_{\text {Corr }}$ was about $1.12 \mu \mathrm{A} \mathrm{cm} \mathrm{cm}^{-2}$, and then decreased to 0.849 $\mu \mathrm{A} \mathrm{cm}{ }^{-2}$ for HAP and to $0.812 \mu \mathrm{A} \mathrm{cm} \mathrm{cm}^{-2}$ for $\mathrm{HAP}-\mathrm{SiO}_{2}$ bilayer coating. The $i_{\text {Corr }}$ of H80T20-S specimens which is about $0.724 \mu \mathrm{A} \mathrm{cm} ~^{-2}$ indicates that they are more corrosion resistant than $\mathrm{H} 50 \mathrm{~T} 50\left(\simeq 0.758 \mu \mathrm{A} \mathrm{cm}^{-2}\right)$ and H80T20 $\left(\simeq 0.801 \mu \mathrm{A} \mathrm{cm}{ }^{-2}\right)$, which are in turn more resistant than $\mathrm{HAP}-\mathrm{SiO}_{2}$. When compared to other specimens, H50T50-S exhibits a lower corrosion current $\left(\simeq 0.251 \mu \mathrm{A} \mathrm{cm}^{-2}\right)$. The noble behavior of the coated 316L SS samples can be attributed to the denser nature of the coating surface, due to the formation of apatite precipitates resulting from the reaction between the calcium and phosphate ions in the SBF solution. Indeed, the presence of the $\mathrm{SiO}_{2}$ inner layer prevents the electrolyte to infiltrate into the deeper portion of the coating through the pores and cracks existing in the coating causing pitting corrosion. A passive current plateau is noticed on the potentiodynamic polarization curves recorded on $\mathrm{HAP}_{-} \mathrm{SiO}_{2}$ (Figure 5(d)), H80T20 (Figure 5(e)), and H80T20-S (Figure 5(f)). The passivation behavior indicates that protective surface films have been formed on the surface of the specimens exposed to the SBF solution. Potentiodynamic curves recorded on H50T50 (Figure 5(b)) and H50T50-S (Figure 5(c)) are quite similar. The anodic current density increased with increasing potential suggesting the formation of a thin oxide film on the surface of the coatings. The further increase of the anodic current density suggests a degradation of that passive film. ${ }^{[37,38]}$ Thus, the reinforcement of the HAP coating with $\mathrm{TiO}_{2}$ and $\mathrm{SiO}_{2}$ improved the corrosion resistance of the $316 \mathrm{~L}$ steel substrate. It is noted that the increase of $\mathrm{TiO}_{2}$ concentration in the hydroxyapatite phase considerably increased the uniformity of the coatings and thereby decreased the surface roughness. ${ }^{[15]}$ After the insertion of $\mathrm{SiO}_{2}$ inner layer on $316 \mathrm{~L}$ SS substrate, H50T50-S bilayer coating showed a smooth surface, (see Table II; Figure 2) and exhibited a higher corrosion resistance. The significantly reduced corrosion current density in the H50T50-S $\left(\simeq 0.251 \mu \mathrm{A} \mathrm{cm}{ }^{-2}\right)$ clearly demonstrates the improvement obtained in the corrosion resistance. The surface roughness and surface morphology can considerably change corrosion and corrosion rate. A higher corrosion resistance is obtained for surfaces with lower roughnesses. ${ }^{[39]}$

\section{Bonding Strength}

Figure 6A shows the optical microscopy images corresponding to the scratch track realized on the surface of coatings during the scratch force test. Load is progressively increasing from right to left. According to Figure 6A, no visible wear debris were come out from the coatings in the initial stage of small-applied load (Figure 6A(a, c, e, g)). As the load was increased, the cracks appeared on the surface and became more severe until the delamination of the coating from the substrate (Figure 6A(b, d, f, i)). The corresponding load is recorded as the critical load Lc. No important damage is inspected on the scratching surface corresponding to H50T50-S coating (Figure 6A(h)), the failure was occurred only once the load is increased as it is shown in Figure 6A(i). The critical loads $\left(\mathrm{Lc}_{1}, \mathrm{Lc}_{2}, \mathrm{Lc}_{3}\right.$, and $\mathrm{Lc}_{4}$ ) at which the coating was removed from the substrate are indicated with white arrow in Figure $6 \mathrm{~A}(\mathrm{~b}, \mathrm{~d}, \mathrm{f}, \mathrm{i})$, respectively. They are determined from the curves illustrated in Figure $6 \mathrm{~B}$ which presents load as a function of the scratch length (displacement) and are regrouped in Table IV. From Table IV, it can be observed that the insertion of the $\mathrm{SiO}_{2}$ inner layer improved the bonding strength of the H80T20 composite coating to the substrate. H80T20 presents approximately a critical load ( $\left.\mathrm{Lc}_{1}\right)$ of $4820 \mathrm{mN}$, while H80T20-S presents approximately a critical load $\left(\mathrm{Lc}_{2}\right)$ of $4980 \mathrm{mN}$. Addition of $50 \mathrm{vol}$ pet $\mathrm{TiO}_{2}$ to HAP also improves the bonding strength compared to H80T20. In literature, ${ }^{[37]}$ it is indicated that an increase in the $\mathrm{TiO}_{2}$ particles content in HAP matrix leads to the formation of dense coatings with low porosity, thus resulting in coatings with higher hardness and adhesive strength. The H50T50 coating presents approximately a critical load $\left(\mathrm{Lc}_{3}\right)$ of $5050 \mathrm{mN}$. With the addition of the $\mathrm{SiO}_{2}$ inner layer on the substrate, the H50T50-S bilayer coating presents a higher bonding strength $\left(\mathrm{Lc}_{4} \simeq 5680 \mathrm{mN}\right)$. The $\mathrm{SiO}_{2}$-hydroxylated surface can therefore promote the attachment of the $\mathrm{TiO}_{2} / \mathrm{HAP}$ layer on the substrate. As illustrated in Figure 7, such an effect could be due to the formation of Si-O-Ti bridge linking at the interface. The mechanism involved in this interaction is the possibility of the formation of hydrogen bond between the silanol groups, $\mathrm{Si}-\mathrm{OH}$, present on the surface of the $\mathrm{SiO}_{2}$ film and the Ti-OH or Ti-OR groups $\left(\mathrm{R}=\mathrm{OC}_{3} \mathrm{H}_{7}\right)$ bonded to the ends of the alkoxide molecules $\mathrm{Ti}(\mathrm{OH})_{y}\left(\mathrm{OC}_{3} \mathrm{H}_{7}\right)_{4-y}$ after the hydrolysis of titanium isopropoxide in 2-methoxy ethanol and water, ${ }^{[40]}$ according to the reaction: 


$$
\left\{\begin{array}{c}
-\mathrm{Ti}-\mathrm{OH}+\mathrm{HO}-\mathrm{Si}-\rightarrow-\mathrm{Ti}-\mathrm{O}-\mathrm{Si}+\mathrm{H}_{2} \mathrm{O} \\
-\mathrm{Ti}-\mathrm{OR}+\mathrm{HO}-\mathrm{Si}-\rightarrow-\mathrm{Ti}-\mathrm{O}-\mathrm{Si}+\mathrm{ROH}
\end{array}\right.
$$

This mechanism is similar to condensation reactions taking place during the sol-gel polymerization process as illustrated in Figure 7. A similar mechanism has been proposed in the research work of Houmard. ${ }^{[41]}$

It is reported that the coating thickness should be controlled in such a way as to produce a compromise between the bonding strength and the corrosion properties. ${ }^{[42,43]}$ Therefore, the H50T50-S thickness (1310 $\mathrm{nm}$ ) obtained in this study was observed to be the optimized coating for improving both the corrosion resistance and the bonding strength.

\section{E. Mechanical Properties}

For hardness measurements of hard coatings on soft substrate, some authors ${ }^{[44,45]}$ indicate a value close to 10 pct of the coating thickness for the indenter penetration after which the substrate interferes with the measurement. This value can reach 50 pct in the case of soft coating on hard substrate. ${ }^{[46]}$ Unfortunately, this limit which can vary in a great extent is not a predictable value because it depends both on coating thickness and on the mechanical behavior of the coating, i.e., for a hard coating on a soft substrate or for a soft coating on a hard substrate. To avoid the application of models for which the above-mentioned limit values cannot be defined precisely, a direct determination of the mechanical properties of the material will be preferable. This is rendered possible by means of the continuous stiffness measurement mode, which allows the computation of both the hardness and the elastic modulus as a function of the indenter penetration. ${ }^{[47]}$ Figure 8 represents the hardness variation as a function of the indenter penetration. As shown in this figure, H50T50 coating presents the highest hardness value close to the external surface. For the indenter penetrations over than $100 \mathrm{~nm}$, the hardness of H50T50 increases notably to reach 2 $\mathrm{GPa}$, while the hardness of H80T20 coating varies slightly. After $200 \mathrm{~nm}$, the hardness of H50T50 coating decreases and tends to that of H80T20. We note that the hardness value of H80T20 and H50T50 coatings can be considered as a constant value for indenter depths between 500 and $800 \mathrm{~nm}$. In this region, the hardness is close to 1.1 and $1 \mathrm{GPa}$ for the H50T50 and H80T20 coatings, respectively. For penetration depths over 800 $\mathrm{nm}$, the hardness continues to increase to achieve a value which should correspond to that of the substrate ( $\simeq 2 \mathrm{GPa}$ ). For the H50T50-S coating, the hardness is rather close to that of H50T50 for indenter penetration close to the outer surface $(100 \mathrm{~nm})$, and then, it is clear to note that the hardness is influenced by the presence of the $\mathrm{SiO}_{2}$ inner layer. Above $550 \mathrm{~nm}$, the hardness value tends to that of H80T20 and H50T50 coatings before reaching the substrate hardness over $800 \mathrm{~nm}$ in depth. The $\mathrm{SiO}_{2}$ inner layer does not improve the hardness measurement.
To determine the elastic modulus of H80T20, H50T50, and H50T50-S coatings, a model must be applied for separating the influence of the substrate on the elastic modulus measurement. Indeed, the limit value for the indenter displacement after which the substrate interferes with the measurement is close to 1 pct of the film thickness for a hard film deposited onto a soft substrate $^{[48,49]}$ and it can reach 20 pct for a soft film deposited onto a hard substrate. ${ }^{[46,50]}$ Several models have been proposed to extract intrinsic material properties of the film from the composite modulus, which represent the combination of the respective moduli of the film, $E_{\text {film }}$, and of the substrate, $E_{\text {substrate. }}$ Most of them are empirical models based on the following relationship:

$$
E_{\text {composite }}=E_{\text {substrate }}+\left(E_{\text {film }}-E_{\text {substrate }}\right) \Phi(x) .
$$

The relative weight $\Phi(x)$ of each material, as was pointed out by Doerner and $\mathrm{Nix}^{\left[{ }^{[50]}\right.}$ varies with the penetration depth. Different weight functions are available in literature, and the most commonly used have been proposed by Doerner and Nix.. ${ }^{[51]}$ Mencik et al. ${ }^{[52]}$ Antunes et al.,$^{[53]}$ and Gao et al. ${ }^{[54]}$ First, we tested the model of Perriot and Barthel ${ }^{[55]}$ who extended the Gao's function to a larger range of moduli ratios and propose the empirical model in Eq. [5]. This function represents the measured reduced modulus, $E_{\mathrm{RC}}$, as a function of $E_{\mathrm{RF}}$ (obtained for the lowest loads and representing the reduced modulus of the film) and $E_{\mathrm{RS}}$ (obtained for the highest loads and representing the reduced modulus of the substrate):

$$
E_{\mathrm{RC}}\left(\frac{a}{t}\right)=E_{\mathrm{RF}}+\frac{\left(E_{\mathrm{RS}}-E_{\mathrm{RF}}\right)}{1+\left(\frac{t x_{0}}{a}\right)^{\mathrm{n}}},
$$

where $x_{0}$ and $n$ are adjustable constants. $a(=\mathrm{h} \cdot \tan \Psi)$ is the contact radius of a assimilated conical indenter at the maximum load, $\Psi$ equals to 70.3 deg corresponding to the half-angle of the tip conical indenter, and $h$ is the indenter displacement and $t$ the film thickness. The parameter $x_{0}$ is the value of the $a / t$ ratio for which $E_{\mathrm{C}}=\left(E_{\mathrm{RS}}+E_{\mathrm{RF}}\right) / 2$. At the same time, it corresponds to the change in curvature of the $\left(E_{\mathrm{C}} ; a / t\right)$ curve plotted in semi-log coordinates.

Additionally, we tested the model suggested by Roudet et al. ${ }^{[56]}$ using the mathematical expression similar to that proposed by Avrami ${ }^{[57,58]}$ :

$$
E_{\mathrm{C}}=E_{\mathrm{F}}+\left(E_{\mathrm{S}}-E_{\mathrm{F}}\right) \exp \left[-k_{\mathrm{s}} \cdot \Phi^{\mathrm{n}_{\mathrm{s}}}\right],
$$

where $E_{\mathrm{C}}$ is the composite elastic modulus and $E_{\mathrm{F}}, E_{\mathrm{S}}$ are, respectively, the elastic modulus of the film and of the substrate. $K_{\mathrm{S}}, n_{\mathrm{S}}$ are fitting coefficients, which indicate the magnitude of the curve, and the weight function $(\Phi)$ is given by equation Eq. [7]:

$$
\begin{aligned}
\Phi= & \frac{2}{\pi} \arctan \left(\frac{t}{a}\right)+\frac{1}{2 \pi\left(1-v_{\mathrm{c}}\right)} \\
& \times\left[\left(1-2 v_{\mathrm{c}}\right) \frac{t}{a} \ln \left(1+\left(\frac{a}{t}\right)^{2}\right)-\frac{\frac{a}{t}}{1+\left(\frac{a}{t}\right)^{2}}\right] .
\end{aligned}
$$


Finally, Figure 9 presents the two models applied on the complete range of indentation data. The elastic modulus is represented as a function of the weight function $(\Phi)$ and of the ratio $(a / t)$. The H80T20 (Figure 9(a) and (b)) and H50T50 (Figure 9(c) and (d)) curves seem to be satisfactorily represented in all the range of the indentation data. In the range of $a / t$ $=0-0.2$ and $\Phi=0.9-1$ for the indentation penetration lower than $100 \mathrm{~nm}$, there is some variation in the indentation data related to the insufficient precision of the influence of the indenter tip defect involved in the computation of the contact area. Even the representations are not linear, and the tendencies at the two limits $(a / t=0.2)$ and $(\Phi=0.9)$ converge toward the elastic moduli of the film. The results of both the elastic modulus of the film and of the substrate as well as the fitting parameters are listed in Table $\mathrm{V}$. The values given by the two models are very similar. For the H50T50-S coating (Figure 9(e) and (f)) when $\Phi$ is lower than 0.7 and the ratio $a / t$ is higher than 1 (for indenter displacements higher than $400 \mathrm{~nm}$ ), the elastic modulus variation is adequately represented and tends toward that of H50T50 coating (33 GPa). When $\Phi$ is higher than 0.7 and the ratio $\mathrm{a} / \mathrm{t}$ is lower than 1 (for indenter displacements less than $470 \mathrm{~nm}$ ), the elastic modulus variation is not adequately represented by the fitting curves. This tendency can be due to the presence of the $\mathrm{SiO}_{2}$ inner layer.

The hardness and the elastic modulus of the prepared coatings are found to increase as the content of the $\mathrm{TiO}_{2}$ increases to $50 \mathrm{vol}$ pct. H50T50 possesses the hardness value of $2 \mathrm{GPa}$ at the surface, $1.1 \mathrm{GPa}$ in the core of the coating, and the elastic modulus value of $33 \mathrm{GPa}$. The hardness variation between the surface and the core of the coating was explained by the initial deposition of some $\mathrm{TiO}_{2}$ on the underlying substrate, while the remaining $\mathrm{TiO}_{2}$ formed a composite with HAP and produced the structure. ${ }^{[16]}$ Further deeper analysis about the mechanical properties of the $\mathrm{SiO}_{2}$ film will be investigated in the future studies in order to explain the influence of the mechanical behavior of the intermediate $\mathrm{SiO}_{2}$ layer.

It is noted that the hardness values measured in this study, which are comparable with those reported previously for pure HAP ceramics $(1.0-5.5 \mathrm{GPa}){ }^{[59]}$ are able to withstand large abrasion forces during implant insertion. The elastic modulus has attracted much research interest because of its critical importance for characterizing various bone pathologies and guiding artificial implant design. The equivalent elastic modulus must be adjusted to not greatly exceed those of bones in order to avoid stress shielding at the bone-implant interface, a major source for bone resorption and eventual failure of the implants. The elastic moduli values measured here are comparable with those of cortical bone (compact bone) ranging from 3 to 30 GPa ${ }^{[60,61]}$ H80T20 and H50T50 coatings are promising materials for the hard tissue application. Owing to its higher corrosion resistance and bonding strength, H50T50-S-coated-316L SS has a potential application in orthopedic as a prosthetic implant. Further studies are required to test the bioactivity and biocompatibility of these promising biomedical materials in vitro and in vivo. Recently, published work ${ }^{[62]}$ has shown that the $\mathrm{TiO}_{2} / \mathrm{HAP}$ (20 vol pct $\mathrm{TiO}_{2}$ ) composite coatings exhibited well biocompatible properties, stem cells attached well onto the surface, proliferated, and presented a polygonal morphology different from the fibroblastic-like morphology found on 316L SS. Moreover, $\mathrm{TiO}_{2} / \mathrm{HAP}$ composite improved the corrosion resistance of the 316L SS implant and showed mechanical properties close to that of hard tissue once incubated in physiological conditions for 7 days, highlighting its potential application in hard tissue replacement.

\section{CONCLUSION}

The 50 vol pet $\mathrm{TiO}_{2}$-reinforced HAP layer has been successfully attached on the surface of silica-coated $316 \mathrm{~L}$ SS by sol-gel method. The surface properties of silica inner layer enhanced the attachment of the $\mathrm{TiO}_{2}$ and HAP phases through the $\mathrm{Si}-\mathrm{OH}$ hydroxyl groups and the chemical affinity of $\mathrm{TiO}_{2}$ toward the HAP, thus suggesting an improvement in the corrosion resistance, bonding strength, elastic modulus, and hardness of the coated 316L SS required for the hard tissue application.

\section{ACKNOWLEDGMENTS}

This study was funded by the University of Bejaia from Algeria. The authors are very grateful to MSMP, Arts et Métiers ParisTech of Lille, France, for the help in providing the mechanical analysis.

\section{REFERENCES}

1. E.C. Shores, R.E. Holmes: An Introduction to Bioceramics, in: L.L. Hench, J. Wilson (Eds.), World Scientific: Singapore, 1993, pp. 181-98.

2. Marc Long, H.J. Rack: Biomaterials, 1998, vol. 19, pp. 1621-39.

3. M. Navarro, A. Michiardi, and O. Castaño: J.A PlanellJ. R. Soc. Interface, 2008, vol. 5, pp. 1137-58.

4. H. Hermawan, D. Ramdan, J.R.P. Djuansjah: Metals for Biomedical Applications, Biomedical Engineering - From Theory to Applications, Prof. Reza Fazel (Ed.), InTech, Available from: http://www.intechopen.com/books/biomedical-engineering-fromtheory-toapplications/, 2011.

5. V.P. Mantripragada, B. Lecka-Czernik, N.A. Ebraheim, and A.C. Jayasuriya: J Biomed Mater Res A, 2013, vol. 101, pp. 3349-64.

6. M. Navarro, A. Michiardi, O. Castano, and J. Planell: J. R. Soc. Interface, 2008, vol. 5, pp. 1137-58.

7. J.A. Disegi and L. Eschbach: Injury, 2000, vol. 31, pp. 2-6.

8. J. Blumn, K.L. Eckert, A. Schroeder, M. Petitmermet, S.W. Ha, E. Wintermantel: Proceedings of the 9th International Symposium on Ceramics in Medicine, in: T. Kokubo, T. Nakamura, F. Miyaji (Eds.), Col. 9, Otsu, Japan, 1996, pp. 89.

9. S. Nagarajan and N. Rajendran: Appl. Surf. Sci., 2009, vol. 255, pp. 3927-32.

10. H.W. Kim, Y.H. Koh, L.H. Li, S. Lee, and H.E. Kim: Biomaterials, 2004, vol. 25, pp. 2533-38.

11. C.E. Wen, W. Xu, W.Y. Hu, and P.D. Hodgson: Acta Biomater., 2007, vol. 3, pp. 403-10.

12. T.P. Singh: Harpreet SinghHazoor Singh: J. Therm. Spray Technol., 2012, vol. 21, pp. 917-27.

13. P.C. Rath, L. Besra, B.P. Singh, and S. Bhattacharjee: Ceram. Inter., 2012, vol. 38, pp. 3209-16. 
14. D. Sidane, D. Chicot, S. Yala, F. Bir, H. Khireddine, S. Ziani, A. Iost, and X. Decoopman: Thin Solid Films, 2015, vol. 593, pp. 71-80.

15. A.J. Nathanael, N. Sabari Arul, N. Ponpandian, D. Mangalaraj, and P.C. Chen: Thin Solid Films, 2010, vol. 518, pp. 7333-38.

16. A.J. Nathanael, D. Mangalaraj, and N. Ponpandian: Compos. Sci. Technol., 2010, vol. 70, pp. 1645-51.

17. H. Li, K.A. Khor, and P. Cheang: Biomaterials, 2003, vol. 24, pp. 949-57.

18. P. Li, C. Ohtsuki, T. Kokubo, K. Nakanishi, N. Soga, T. Nakamura, and T. Yamamuro: J. Am. Ceram. Soc, 1992, vol. 75, pp. 2094-97.

19. P. Li, C. Ohtsuki, T. Kokubo, K. Nakanishi, N. Soga, and K. de Groot: J Biomed Mater Res, 1994, vol. 28, pp. 7-15.

20. P. Galliano, J.J. Damborenea, M.J. Pascual, and A. Duran: J. Sol-Gel Sci. Technol., 1998, vol. 13, pp. 723-27.

21. S. Kim and P.N. Kumta: Mater. Sci. Eng. B, 2004, vol. 111, pp. 232-36.

22. A. Balamurugan, S. Kannan, and S. Rajeswari: Mater. Lett., 2005, vol. 59, pp. 3138-43.

23. T. Kokubo and H. Takadama: Biomaterials, 2006, vol. 27, pp. $2907-15$.

24. J.E. Field and R.H. Telling: The young modulus and poisson ratio of diamond, Research Note, Cavendish Laboratory, Cambridge, 1999.

25. M. Houmard, E.H.M. Nunes, D.C.L. Vasconcelos, G. Berthomé, J.-C. Joud, M. Langlet, and W.L. Vasconcelos: Appl. Surf. Sci., 2014, vol. 289, pp. 218-23.

26. S. Permpoon, G. Berthomé, B. Baroux, J.C. Joud, and M. Langlet: J. Mater Sci., 2006, vol. 41, pp. 7650-62.

27. L. Zhang, Z. Xing, H. Zhang, Z. Li, X. Wu, X. Zhang, Y. Zhang, and W. Zhou: Appl Catal B., 2016, vol. 180, pp. 521-29.

28. P.K. Jal, M. Sudarshan, A. Saha, S. Patel and B.K. Mishra: Colloids Surf. A: Chem. Phys. Eng. Asp., 2004, vol. 240, pp. 173-78.

29. V.A. Ermoshin, K.S. Smirnov, and D. Bougeard: Surf. Sci., 1996, vol. 368, pp. 147-51

30. N. Primeau, C. Vautey, and M. Langlet: Thin Solid Films, 1997, vol. 310, pp. 47-56.

31. M. Houmard, D. Riassett, F. Roussel, A. Bourgeois, G. Berthomé, J.C. Joud, and M. Langlet: Surf. Sci., 2008, vol. 602, pp. $3364-74$.

32. D. Sidane, H. Khireddine, S. Yala, S. Ziani, F. Bir, D. Chicot: Metall. Mater. Trans. B, 2015, vol. 46 B, pp. 2340-47.

33. C. Ergun: J Eur Ceram Soc, 2008, vol. 28, pp. 2137-49.

34. C.C. Ribeiro, I. Gibson, and M.A. Barbosa: Biomaterials, 2006 , vol. 27 , pp. 1749-61.

35. H. Anmin, L. Ming, C. Chengkang, and M. Dali: J. Mol. Catal. A: Chem., 2007, vol. 26, pp. 779-85.

36. S. Yala, H. Khireddine, D. Sidane, S. Ziani, and F. Bir: J. Mater. Sci., 2013, vol. 48, pp. 7215-23.

37. S. Yugeswaran, A. Kobayashi, A. Hikmet Ucisik, and B. Subramanian: Appl. Surf. Sci., 2015, vol. 347, pp. 48-56.
38. Y. Huang, Q. Ding, X. Panga, and S. Hana: Y. YanAppl. Surf. Sci., 2013, vol. 282, pp. 456-62.

39. A.S. Toloei, A. Stoilov, and D.O. Northwood: WIT Transactions on Engineering Science, 2013, vol. 77, pp. 193-204.

40. A. Balamurugan, S. Kannan, and S. Rajeswari: Mater. Lett., 2005, vol. 59, pp. 3138-43.

41. M. Houmard: PhD. Thesis, INP Grenoble, France, 2009.

42. B. Aksakal, M. Gavgali, and B. Dikici: J. Mater. Eng. Perform, 2010, vol. 19, pp. 894-99.

43. A. Büyüksagisa, N. Çiftçi, Y. Ergün, and Y. Kayali: Prot. Met. Phys. Chem., 2011, vol. 47, pp. 670-79.

44. H. Buckle:The Science of hardness testing and its research applications in ASM, J.W. Westbrook and H. Conrad, eds., Metals Park, OH, 1973, pp. 453-91.

45. Y. Sun, T. Bell, and S. Zheng: Thin Solid Films, 1995, vol. 258, pp. $198-204$

46. Z.H. Xu and D. Rowcliffe: Thin Solid Films, 2004, vols. 447-448, pp. 399-405.

47. W.C. Oliver and G.M. Pharr: J. Mater. Res, 1992, vol. 7, pp. 1564-83.

48. T. Chudoba, N. Schwarzer, and F. Richter: Surf. Coat. Technol., 2002, vol. 154, pp. 140-51.

49. F. Cleymand, O. Ferry, R. Kouitat, A. Billard, and J. von Stebut: Surf. Coat. Technol., 2005, vol. 200, pp. 890-93.

50. T. Ohmura, S. Matsuoka, K. Tanaka, and T. Yoshida: Thin Solid Films, 2001, vol. 385, pp. 198-204.

51. M.F. Doerner and W.D. Nix: J. Mater. Res., 1986, vol. 1, pp. $601-09$.

52. J. Mencik, D. Munz, E. Quandt, E.R. Weppelmann, and M.V. Swain: J. Mater. Res., 1997, vol. 12, pp. 2475-92.

53. J.M. Antunes, J.V. Fernandes, N.A. Sakharova, M.C. Oliveira, and L.F. Menezes: Int. J. Solids Struct., 2007, vol. 44, pp. 8313-34.

54. H. Gao, C.H. Chiu, and J. Lee: Int. J. Solids. Struct., 1992, vol. 29, pp. 2471-92.

55. A. Perriot and E. Barthel: J. Mater. Res., 2004, vol. 19 (02), pp. 600-08.

56. F. Roudet, D. Chicot, X. Decoopmana, A. Iost, J. Bürgi, J. Garcia-Molleja, L. Nosei, and J. Feugeas: Thin Solid Films, 2015, vol. 594, pp. 129-37.

57. M. Avrami: J. Chem. Phys., 1940, vol. 8, pp. 212-24

58. M. Avrami: J. Chem. Phys., 1941, vol. 9, pp. 177-84.

59. J. Song, Y. Liu, Y. Zhang, and L. Jiao: Mater. Sci. Eng. A, 2011, vol. 528, pp. 5421-27.

60. X. Wang, S. Xu, S. Zhou, W. Xu, M. Leary, P. Choong, M. Qian, M. Brandt, and Y. Min: Xie: A reviewBiomaterials, 2016, vol. 83, pp. $127-41$.

61. A.J. Nathanael, Y.M. Ima, T.H. Oha, R. Yuvakkumarb, and D. Mangalarajc: Appl. Surf. Sci., 2015, vol. 332, pp. 368-78.

62. D. Sidane, H. Rammal, A. Beljebbar, S.C. Gangloff, D. Chicot, F. Velard, H. Khireddine, A. Montagne, and H. Kerdjoudj: Mater. Sci. Eng. C, 2017, vol. 72, pp. 650-58. 